\title{
Politiets brug af peberspray
}

\author{
AfLisbeth Garly Andersen ${ }^{1}$ og Peter Vedel Kessing ${ }^{2}$
}

\begin{abstract}
This article discusses the use of pepper spray by police since its introduction to Denmark in 2008. Pepper spray contains pepper extract and has been assessed as capable of causing serious health risks by the Danish Health Authority. International human rights bodies have also expressed concerns about the use of pepper spray. Despite this, no comprehensive study or evaluation of the use of pepper spray has ever been conducted in Denmark. The article uses qualitative interviews with police officers and people exposed to pepper spray, as well as a review of reports from police officers about their use of pepper spray, in an examination of whether Danish rules and practices fully comply with human rights requirements and recommendations. The situations in which pepper spray is typically used are described with a focus on where it is used and who it is used against. The authors express concern about the use of pepper spray in a number of situations and argue that its authorization should be more restrictive and precisely regulated. Finally, the article describes a dialogue with the Danish National Police and the pending police act regulating pepper spray.
\end{abstract}

\section{Introduktion}

»Det er begrænset, hvor lang tid man vil stå og høre på det [at en person modsætter sig verbalt, red.], når man er ved at lave en lovlig anholdelse og er nødt til at sikre hans tilstedeværelse. Der vil måske ikke gå ret lang tid, før man siger: 'Ved du hvad, du får peberspray, hvis du ikke vil komme med frivilligt'.« (Interview med politibetjent om, hvornår peberspray benyttes, Institut for Menneskerettigheder 2014) (IP 4).

Danmark indførte 1. januar 2008 peberspray som et nyt magtmiddel for politiet. ${ }^{3}$ Peberspray er en væske, der består af peberekstrakt og påfører den ramte person akut øjenkrampe med deraf følgende midlertidig blindhed, som normalt varer ca. 30-45 minutter. Pebersprayen medfører endvidere stærk smerte i øjnene og

* Title in English: Police use of pepper spray. 
hudsvie. ${ }^{4}$ Siden indførelsen er peberspray blevet det absolut mest anvendte indberetningspligtige magtmiddel.

I forbindelse med indførelsen af peberspray oplyste Sundhedsstyrelsen om risici forbundet med anvendelse af peberspray, særligt hvis den eksponerede person lider af luftvejssygdomme eller er påvirket af rusmidler. Sundhedsstyrelsen påpegede desuden, at peberspray burde begrænses mest muligt og kun anvendes af særligt uddannet personnel efter særlig instruks. ${ }^{5}$

Herudover har Rigsadvokaten og Den Uafhængige Politiklagemyndighed kritiseret enkelte sager, hvor peberspray er blevet anvendt af politiet. Ligesom Østre Landsret har kvalificeret et civilt angreb med peberspray som vold af særlig rå, brutal eller farlig karakter omfattet af $\S 245$ i straffeloven. Dertil kommer, at en række internationale menneskeretlige institutioner har udtrykt bekymring over brug af peberspray.

Siden indførelsen af peberspray har brugen af sprayen imidlertid ikke været genstand for systematisk diskussion i Danmark, ligesom den praktiske anvendelse ikke er undersøgt nærmere. ${ }^{6}$

Institut for Menneskerettigheder besluttede på den baggrund at gennemføre en undersøgelse af brugen af peberspray i politiet. Formålet med undersøgelsen, der blev gennemført i 2014, var at belyse, hvordan peberspray anvendes i praksis, og vurdere om anvendelsen stemmer overens med Danmarks internationale forpligtelser. I denne artikel fremlægges de vigtigste resultater af undersøgelsen og de væsentligste anbefalinger. ${ }^{7}$ Afslutningvist beskrives, hvilken reaktion undersøgelsen har afstedkommet i politiet. Ligesom der redegøres for det nye forslag til politilov, som justitsministeren fremsatte i oktober 2016, hvor politiets brug af peberspray præciseres, skærpes og lovreguleres.

\section{Anvendte metoder og kildemateriale}

For at få et indtryk af, hvordan peberspray anvendes af politiet, er der i forbindelse med undersøgelsen anvendt kvalitative metoder i form af interviews med betjente og personer, der har været udsat for peberspray af politiet. Dette er suppleret med en dokumentanalyse af politiets indberetninger om brug af peberspray, som instituttet har fået aktindsigt i. Herudover er klager fra personer, der er blevet eksponeret for peberspray, blevet gennemgået, såvel som afgørelser på disse klager fra Politiklagemyndigheden (DUP). De kvalitative data er suppleret med talmateriale fra Rigspolitiet, som instituttet har fået aktindsigt $i$, samt offentlig statistik. De kvalitative metoder og gennemgangen af talmaterialet er efterfølgende kombineret med en juridisk analyse af gældende dansk ret og relevante menne- 
skeretlige bestemmelser. De kvalitative metoder gennemgås nærmere i det følgende.

I forbindelse med undersøgelsen er 161 indberetninger blevet gennemgået. Indberetningerne dækker brugen af peberspray i 2012 i en tilfældig udvalgt politikreds. ${ }^{8}$ Hver gang peberspray bliver anvendt, har politiet pligt til at udfærdige en indberetning i form af et skema, der skal udfyldes. Alle indberetningerne, som instituttet har gennemgået, var anonymiserede og indeholdt oplysninger om baggrunden for anvendelsen af peberspray og en kort beskrivelse af hændelsesforløbet. Nogle indberetninger indeholdt kun fă linjers beskrivelse, andre var mere detaljerede. Instituttet har på baggrund af disse indberetninger foretaget en samlet beskrivelse af sagerne ud fra forskellige parametre, herunder de situationer, magtanvendelse typisk er foregået $\mathrm{i}$, hvor magtanvendelsen har fundet sted og så videre. Det skal bemærkes, at indberetningerne udelukkende rummer betjentenes udlægning af et hændelsesforløb.

Der er i alt gennemført 19 interviews af politibetjente i tre politikredse, nemlig Fyns Politi, Københavns Vestegns Politi og Nordsjællands Politi. Kredsene er blevet udvalgt af Rigspolitiet. Herudover er en repræsentant fra politiets efteruddannelsescenter blevet interviewet såvel som to repræsentanter fra Rigspolitiets Center for Flåde og Materielstyring, der har ansvaret for peberspray såvel som andre magtmidler. De interviewede betjente indgik på forskellige niveauer i organisationen og bestred forskellige funktioner. Langt de fleste var dog almindelige betjente uden ledelsesansvar. Alle de interviewede var mænd, bortset fra én kvindelig betjent. Alle informanter i politikredsene er foreslået af politiet. De interviewede betjente har alle enten selv anvendt peberspray eller set peberspray blive anvendt.

Som led i undersøgelsen har instituttet også ønsket at tale med personer, der har været eksponeret for peberspray. Kriminalforsorgen har hjulpet med kontakt til disse mennesker, da politiet ikke har været i stand til/ønsket at formidle denne kontakt. Hensigten med disse interviews var primært at få indsigt i, hvordan det opleves at blive udsat for peberspray, og få nogle eksempler på situationer, hvor peberspray er blevet anvendt af politiet - ud fra de berørtes perspektiv. Syv personer er blevet interviewet. Alle var indsat $i$ en af Kriminalforsorgens institutioner på tidspunktet for interviewet. Det er også her, interviewene har fundet sted. Instituttet havde adgang til de pågældende fængsler/arresthuse som led i en tilsvarende undersøgelse om peberspray i Kriminalforsorgen. ${ }^{9}$ Fordi de interviewede kun består af indsatte (og dermed personer, der er blevet anholdt af politiet og efterfølgende har fået en dom), er de ikke nødvendigvis repræsentative for gruppen af personer, som peberspray anvendes imod. 
Interviewene med betjente er i alle tilfælde foretaget i rolige omgivelser uden forstyrrelser, primært på deres kontor. Enkelte samtaler har fundet sted på instituttet. Bortset fra interviewet med Rigspolitiets Center for Flåde og Materielstyring, hvor to personer var til stede, er alle betjente blevet udspurgt individuelt. Interviewene med indsatte er foregået $\mathrm{i}$ afhørings- eller besøgsrum og har fundet sted uden afbrydelser. Der har ikke været nogen betjente til stede under interviewene.

Størstedelen af de 28 interviews med betjente og indsatte er blevet optaget digitalt, og 15 interviews er blevet udskrevet i deres fulde ordlyd. I fem af de interviews, der ikke blev transskriberet, var der en forsker og en assistent til stede, hvor den ene nedskrev interviewet direkte. Interviewene med betjente såvel som indsatte tog udgangspunkt i semistrukturerede interviewguider med åbne spørgsmål.

Instituttet har garanteret alle informanter fuld anonymitet, og kun instituttet har adgang til lydfiler og interviewudskrifter, som bliver opbevaret fortroligt.

\section{Hvor ofte bruges peberspray?}

Ifølge statistik fra Rigspolitiet er peberspray blevet brugt 9.215 gange i perioden 2008-2014. Dette svarer til, at magtmidlet i gennemsnit bliver brugt knap fire gange om dagen i hele landet. Indberetningerne om politiets brug af peberspray fordeler sig som følger:

\section{Tabel 1. Oversigt over brugen af peberspray 2008-2014}

\begin{tabular}{lcccccccc}
\hline & $\mathbf{2 0 0 8}$ & $\mathbf{2 0 0 9}$ & $\mathbf{2 0 1 0}$ & $\mathbf{2 0 1 1}$ & $\mathbf{2 0 1 2}$ & $\mathbf{2 0 1 3}$ & $\mathbf{2 0 1 4}$ & Total \\
\hline Antal indberetninger $^{10}$ & 1.457 & 1.427 & 1.290 & 1.654 & 1.428 & 1.149 & 810 & 9.215 \\
\hline
\end{tabular}

Tabel 1 viser, at brugen af peberspray er faldet siden 2011. Mens antallet af indberetninger løb op i 1.654 i 2011, faldt det i 2012 til 1.428, til 1.149 i 2013 og endelig til 810 i 2014 . Dette er det laveste antal anvendelser, siden peberspray blev indført som standardudrustning i politiet. Rigspolitiet forklarer faldet i de senere år med, at uromagere i højere grad er blevet bevidst om magtmidlets virkninger og dermed nemmere lader sig dæmpe ned, uden at det er nødvendigt at tage sprayen i brug. ${ }^{11}$ Politiet råder også over skydevåben, politistav, gas og tjenestehunde. Disse magtmidler bruges imidlertid i et langt mindre omfang. ${ }^{12}$

Peberspray anvendes fortrinsvis, når politiet møder det, der betegnes som »aktiv modstand«, eller når politiet afværger et angreb mod en person. Disse sager 
udgør henholdsvis 67 procent og 49 procent af sagerne i 2012. ${ }^{13}$ Herudover anvendes peberspray ved passiv modstand (9 procent af sagerne i 2012). Fordelingen ser ud som følger:

Tabel 2. Oversigt over grunde til at anvende peberspray 2008-2012 $2^{14}$

\begin{tabular}{lrrrrrrr}
\hline & $\mathbf{2 0 0 8}$ & $\mathbf{2 0 0 9}$ & $\mathbf{2 0 1 0}$ & $\mathbf{2 0 1 1}$ & $\mathbf{2 0 1 2}$ & $\mathbf{2 0 1 3}$ & $\mathbf{2 0 1 4}$ \\
\hline $\begin{array}{l}\text { Afværgelse af angreb mod person el- } \\
\text { ler fare for personers liv eller helbred }\end{array}$ & $50 \%$ & $50 \%$ & $46 \%$ & $56 \%$ & $49 \%$ & & - \\
\hline $\begin{array}{l}\text { Afværgelse af angreb på samfundsvig- } \\
\text { tige institutioner eller ejendom }\end{array}$ & $2 \%$ & $1 \%$ & $1 \%$ & $2 \%$ & $1 \%$ & & - \\
\hline Overvinde aktiv modstand & $58 \%$ & $61 \%$ & $65 \%$ & $75 \%$ & $67 \%$ & - & - \\
\hline Overvinde passiv modstand & $11 \%$ & $8 \%$ & $9 \%$ & $10 \%$ & $9 \%$ & - & - \\
\hline
\end{tabular}

Interviewene med betjente viser, at der er stor forskel på, hvor meget de enkelte har anvendt peberspray. Nogle har enten aldrig anvendt peberspray eller kun anvendt peberspray ganske få gange. Andre har brugt peberspray op til 25 gange. Peberspray er blevet anvendt $\mathrm{i}$ en række forskellige situationer, der vil blive nærmere beskrevet i det følgende.

\section{Hvornår må politiet bruge peberspray}

I dette afsnit gives først et kort overblik over politiets brug af magt og magtmidler og den retlige regulering heraf. Herefter beskrives den retlige regulering af politiets brug af stav, hund og gas. Reguleringen af peberspray beskrives til sidst i kapitlet.

\subsection{Politiets brug af magt og magtmidler-magtbarometeret}

Der tales ofte om et magtbarometer strækkende sig fra:

- Skydevåben

- Politistav

- Hunde

- Gas

- Peberspray

- Håndkraft (umiddelbar fysisk magtanvendelse)

- Talens brug ${ }^{15}$ 
Hvor skydevåben er det mest indgribende magtmiddel og talens brug det mindst. ${ }^{16}$ Der er dog ikke tale om en absolut prioritering, og der skal altid foretages en konkret vurdering af, hvilket magtmiddel der i den givne situation vil være det mindst indgribende. ${ }^{17}$

\subsection{Overblik over den retlige regulering af politiets magtmidler}

Politiloven indeholder i kapitel 4 i $\S \S 14-21$ bestemmelser om politiets anvendelse af magt. Politiloven og de heri indeholdte bestemmelser om politiets magtmidler blev vedtaget i 2004. Før vedtagelsen af politiloven var politiets magtmidler hovedsageligt reguleret administrativt, herunder i kundgørelser fra Rigspolitichefen.

Forslaget til politilov blev udarbejdet af en bredt sammensat Politikommission, der blev nedsat 1998, og som bl.a. skulle overveje behovet for og i givet fald udarbejde forslag til et nyt samlet lovgrundlag for politiets virksomhed.

Politikommissionen anbefalede, at der blev fastsat særlige lovregler om politiets magtanvendelse. Kommissionen anførte:

»Politikommissionen anser det for at være i bedre overensstemmelse med nutidens krav til legalitetsgrundlaget for myndighedsudøvelse, at politiets virksomhed - ikke mindst på de nævnte central områder vedrørende politiets magtanvendelse og indgreb over for borgerne - reguleres direkte af lovgivningsmagten. Udtrykkelige og klare regler på området vil styrke borgernes retssikkerhed samtidigt med, at politiets arbejdsvilkår vil blive forbedret. ${ }^{18}$

Magtanvendelsesbestemmelserne i politiloven suppleres af Justitsministeriets bekendtgørelse om politiets anvendelse af visse magtmidler m.v. fra 2004 (herefter magtanvendelsesbekendtgørelsen). Bekendtgørelsen gengiver politilovens bestemmelser om magtanvendelse og på visse områder præciseres det nærmere, hvornår og hvordan de nævnte magtmidler kan anvendes. ${ }^{19}$

Brugen af peberspray er ikke reguleret i politiloven (bortset fra de generelle bestemmelser om magtanvendelse i $\S$ 14-16). Men ved en ændring af magtanvendelsesbekendtgørelsen i 2007 blev der indsat bestemmelser om politiets brug af peberspray i bekendtgørelsen. ${ }^{20}$ Peberspray blev således et tilladt magtmiddel fra den 1. januar 2008. ${ }^{21}$

Der sondres i politiloven mellem magtanvendelse uden brug af magtmidler, dvs. håndkraft og talens brug, og magtanvendelse ved brug af magtmidler, dvs. skydevåben, stav, hund, gas eller peberspray.

$\mathrm{Al}$ politiets magtanvendelse - med og uden magtmidler - er reguleret af de generelle bestemmelser om magtanvendelse i $\S \S 15-16$ i politiloven, hvori det be- 
skrives, hvornår politiet må anvende magt (§15), og der opstilles nogle generelle beskyttelsesgarantier ( 16$)$. Politiets brug af magt uden magtmidler, dvs. håndkraft (og talens brug), er alene reguleret af disse to generelle bestemmelser, ligesom der ikke er indberetningspligt herfor.

Politiloven og magtanvendelsesbekendtgørelsen opstiller yderligere krav til, hvornår og hvordan politiet kan anvende magtmidler - i form af skydevåben, stav, hund, gas og peberspray. Al anvendelse af magtmidler skal endvidere indberettes til Rigspolitiet. ${ }^{22}$

Magtmidler må således ikke anvendes i alle situationer, hvor politiet må anvende magt efter $\S 15$ i politiloven, men kun i visse nærmere præciserede situationer, som opregnes i $\S \S 17-20$ i politiloven og i magtanvendelsesbekendtgørelsen (indikationsgrundene). Der opstilles endvidere visse specifikke beskyttelsesgarantier for anvendelse af magtmidler i tillæg til de generelle beskyttelsesgarantier i $\S 16$, der gælder for al magtanvendelse.

\subsection{Hvornår må politiet anvende magt og de generelle beskyttelsesgarantier}

Det fastslås i § 15 i politiloven, hvornår politiet må anvende magt, og § 16 opstiller genelle beskyttelsesgarantier, som politiet altid skal iagttage, når de bruger magt. §§15-16 er generelle bestemmelser, der finder anvendelse i forhold til al politiets magtudøvelse. Dvs. både i forhold til magtanvendelse med og uden magtmidler, og herunder også i forhold til peberspray. Politilovens $\S 16$ indeholder fire krav:

For det første skal magtanvendelsen være nødvendig. Det indebærer, at magt kun må anvendes, hvis mindre indgribende midler ikke findes at være tilstrækkelige. Kan den konkrete opgave løses ved, at politiet udsteder fx et påbud mv., må magtanvendelse ikke finde sted. ${ }^{23}$

For det andet skal magtanvendelsen være proportional. Det vil sige, at der skal være et rimeligt forhold mellem den konkrete magtanvendelse og det beskyttede gode. Der kan derfor være tilfælde, hvor politiet må afstå fra at gennemtvinge en myndighedshandling (selvom den er nødvendig), fordi dette vil kræve en magtanvendelse, som ikke står i rimeligt forhold til formålet med handlingen. ${ }^{24}$

For det tredje skal magtanvendelse udføres så skånsomt, som omstændighederne tillader, således at eventuelle skader begrænses til et minimum. Hermed understreges, at politiet skal udøve den faktiske magtanvendelse på en sådan måde, at der forvoldes mindst mulig skade.

Endelig er der for det fjerde krav om, at magtanvendelse er forsvarlig. Det betyder bl.a., at politiet skal tage hensyn til, om der er risiko for, at udenforstående kommer til skade. Det vil sige, at selvom politiets magtanvendelse over for en 
person for så vidt er såvel nødvendig, proportional og skånsom, så kan det alligevel være uforsvarligt at anvende magt over for personen, såfremt der er risiko for at udenforstående personer kommer til skade.

Politiets brug af peberspray må ses og forstås i sammenhæng med politiets brug af øvrige magtmidler. Dertil kommer, at forarbejderne til politiloven 2004 indeholder ganske udførlige beskrivelser og præciseringer af, hvornår politiet kan anvende stav, hund og gas (og skydevåben). Præciseringer, der også kan være relevante i forhold til politiets brug af peberspray.

Nedenfor gennemgås derfor først $\mathrm{i}$ afsnit 4.4. kort reglerne om politiets brug af stav, hund og gas, mens reglerne om peberspray drøftes i afsnit 4.5.

\subsection{Politiets brug af stav, hund og gas}

Politiloven indeholder i $\S \S 17-20$ særlige bestemmelser om politiets brug af stav, hund og gas (samt skydevåben), hvori det nærmere præciseres, i hvilke situationer de pågældende magtmidler kan anvendes (indikationsgrundene 4.4.1.), samt hvilke specifikke beskyttelsesgarantier politiet skal iagttage før, under og efter brugen af det pågældende magtmiddel (4.4.2.).

\subsubsection{I hvilke situationer kan politiet anvende stav, hund og gas (indikationsgrundene)}

Betingelserne for at anvende stav og hund fremgår af $\S 18$ og 19 i politiloven og er i det væsentligste identiske. ${ }^{25}$ Stav og hund kan anvendes i følgende situationer for at:

- Afværge et påbegyndt eller overhængende angreb på person

- Afværge overhængende fare i øvrigt for personers liv eller helbred

- Afværge et påbegyndt eller overhængende angreb på samfundsvigtige institutioner, virksomheder eller anlæg

- Afværge et påbegyndt eller overhængende angreb på ejendom

- Sikre gennemførelse af tjenestehandlinger, mod hvilke der gøres aktiv modstand, eller

- Sikre gennemførelse af tjenestehandlinger, mod hvilke der gøres passiv modstand, såfremt tjenestehandlingens gennemførelse skønnes uopsættelig, og anden og mindre indgribende magtanvendelse skønnes åbenbart uegnet.

Stav og hund kan således grundlæggende anvendes i tre situationer. For at beskytte person; for at beskytte ejendom; eller for at gennemføre tjenestehandlinger, der gøres aktiv eller passiv modstand mod. 
Der må som udgangspunkt ikke anvendes stav eller hund mod personer, der alene yder passiv modstand, og der stilles derfor i disse situationer tillige krav om, at tjenestehandlingen er uopsættelig, $o g$ at mindre indgribende magtmidler er åbenbart uegnede. ${ }^{26}$

Forarbejderne til politiloven fra 2004 indeholder en ganske udførlig beskrivelse af, hvornår politiet må anvende skydevåben, stav, hund og gas. I forhold til brug af stav og hund ved »passiv modstand « anføres det, at hvis kun en eller ganske få personer yder modstand ved at forholde sig passivt, så må det antages, at det »næsten undtagelsesfrit vil være muligt at gennemføre tjenestehandlingen ved brug af almindelig fysisk magt, det vil sige magtanvendelse uden midler. ${ }^{27}$

Det præciseres nærmere i forarbejderne til politiloven fra 2004, hvordan de enkelte kategorier i pkt. 1-6) i § 18 om brug af stav (jf. lige ovenfor) skal forstås. Nedenfor gengives relevante dele af de særlige bemærkninger til lovforslag om politiloven fra $2004::^{28}$

\section{Nr. 1) Personangreb}

Det ikke ethvert personangreb, der kan mødes med anvendelse af stav. Brug af stav skal stå i rimeligt forhold til angrebet. Angreb, der alene kan forvolde mindre skader, som f.eks. blå mærker, mindre rifter og lign., kan ikke begrunde anvendelse af stav.

\section{Nr. 2) Personskade}

Det vil dog ikke være enhver fare for personskade, der kan berettige anvendelse af stav. Magtanvendelsen skal stå i rimeligt forhold til den fare, der søges afværget. Bestemmelsen sigter navnlig til de situationer, hvor politiet anvender magt over for en person af hensyn til den pågældende selv (nødhjælp). Anvendelse af stav vil endvidere kunne være berettiget i situationer, hvor nogen søger at forhindre politiet $i$ at hjælpe en person i fare, f.eks. ved at stille sig i vejen for politiets adgang til det sted, hvor personen befinder sig.

\section{Nr. 3) Angreb på »samfundsvigtige institutioner, virksomheder og anloeg"}

Bestemmelsen omfatter først og fremmest offentlige institutioner med en særlig betydning for samfundets funktion, men også private virksomheder af særlig betydning kan være omfattet. Som eksempler kan nævnes kongehuset, Folketinget, ministerierne, politi- og retsbygninger, jernbaneanlæg, broer, havne, lufthavne, telefonanlæg, radio- og TV-stationer, elektricitetsværker, vandforsyningsanlæg, banker og posthuse samt større eller livsvigtige industrianlæg. 


\section{Nr. 4) Angreb på »ejendom«}

Udtrykket »ejendom《 omfatter angreb på fast ejendom og andre formuegoder. Den økonomiske værdi af godet er ikke i sig selv afgørende for, om der er tale om et angreb omfattet af bestemmelsen. Værdien kan dog have betydning ved vurderingen af, om det vil være nødvendigt og forsvarligt at anvende stav.

\section{Nr. 5) »Aktiv modstand»}

Ved »tjenestehandlinger « forstås bl.a. anholdelse/frihedsberøvelse, påbud, visitation og fratagelse af genstande, eller hvis politiet søger at skaffe sig adgang til et ikke-frit tilgængeligt sted.

Udtrykket »aktiv modstand « kan omfatte en række situationer fra omfattende uroligheder til situationer, hvor en anholdt/pågrebet person holder fast $\mathrm{i}$ en genstand eller andre personer, når politiet forsøger at føre den pågældende væk. Det omfatter også situationer, hvor en pågrebet person forsøger at slå eller rive sig løs fra en polititjenestemands greb, eller hvor en person gør fysisk modstand mod en visitation.

Der kan også være tale om, at tredjemænd forsøger at lægge hindringer i vejen for politiets arbejde, f.eks. at personer forsøger at forhindre en anholdelse eller forsøger at befri en anholdt.

Det følger af straffelovens $\S 119$, stk. 3, at det er strafbart at forsøge at lægge f.eks. politiet hindringer i vejen for udførelse af deres tjeneste eller hverv. Udtrykket »lægger hindringer i vejen« omfatter enhver aktivitet, der lægger hindringer i vejen for udøvelse af politiets tjeneste, og straffelovens $\S 119$, stk. 3 vil således kunne være vejledende for, hvornår der foreligger aktiv modstand mod en tjenestehandling.

\section{Nr. 6) »Passiv modstand»}

Passiv modstand omfatter f.eks. situationer, hvor en anholdt, der ønskes ført væk, ikke følger med, men forholder sig passiv, eventuelt lægger sig ned, og hvor en større menneskemængde stimler sammen til en ulykke, blokerer adgangen til virksomheder mv. og ikke fjerner sig trods politiets påbud herom.

Passiv modstand omfatter også situationer, hvor en anholdt forsøger at undvige ved f.eks. at løbe fra stedet. Hvis den anholdte slår eller river sig fri fra en polititjenestemand for at løbe fra stedet, vil situationen være omfattet af bestemmelsen i nr. 5 om aktiv modstand.

Passiv modstand, der indebærer risiko for nogens liv eller helbred, f.eks. ved at en person blokerer for adgang til en person, der forsøger selvmord eller på anden måde er i fare, vil være omfattet af bestemmelsens nr. 2. Bestemmelsen i nr. 
6 vil således i praksis navnlig omfatte tjenestehandlinger med henblik på at afværge fare for ordensforstyrrelser, bringe strafbar virksomhed til ophør, eller pågribe personer, der har eller med rimelig grund mistænkes for at have begået en forbrydelse.

Det vil som udgangspunkt ikke være forsvarligt at anvende stav mod personer, der alene yder passiv modstand, og der stilles derfor krav om, at tjenestehandlingen skal være uopscettelig, samt at andre og mindre indgribende midler skal skønnes åbenbart uegnede. Hermed præciseres og uddybes kravet om nødvendighed og forsvarlighed i en situation, hvor der bliver tale om at gribe ind over for passiv modstand.

\section{Uopscettelig}

Det må bero på en konkret vurdering og afvejning af flere forhold, herunder navnlig de mulige konsekvenser ved at undlade at gribe ind, om gennemførelse af en tjenestehandling er uopscettelig. Som udgangspunkt må tjenestehandlinger med henblik på at afværge forstyrrelser af vigtige samfundsfunktioner, f.eks. kollektiv transport, brandslukning, ambulancekørsel, hjemmepleje mv., eller at bryde en blokade af en større færdselsåre anses for uopsættelige. Endvidere vil pågribelse/anholdelse af en gerningsmand ofte være en uopsættelig tjenestehandling, navnlig hvis den pågældende træffes under eller i umiddelbar tilknytning til udøvelsen af det forhold, der begrunder anholdelsen.

\section{Mindre indgribende magtmidler er åbenbart uegnede}

Passiv modstand kan udøves af en eller flere personer, og der kan være en forskel i politiets muligheder for at anvende stav i de forskellige situationer. Generelt må antallet af betjente over for antallet af personer, der modsætter sig politiets tjenestehandlinger, samt muligheden for forstærkninger spille en væsentlig rolle ved vurderingen af, om anvendelse af almindelig fysisk kraft er et åbenbart uegnet middel.

Hvis en eller ganske få personer yder modstand ved at forholde sig passivt, må det antages, at det næsten undtagelsesfrit vil være muligt at gennemføre tjenestehandlingen ved brug af almindelig fysisk magt, det vil sige magtanvendelse uden midler.

Yder et større antal personer modstand ved at forholde sig passive, kan det efter omstændighederne være vanskeligere at gennemføre tjenestehandlingen ved hjælp af almindelig fysisk magtudøvelse. Politiet må i sådanne situationer først og fremmest overveje at anvende gas, og kun såfremt dette middel skønnes åbenbart uegnet, vil anvendelse af stav være berettiget.« 
Politiets brug af tåregas er reguleret i $§ 20$ i politiloven. Betingelserne for anvendelse af tåregas er identiske med betingelserne for stav og hund (og peberspray), dog således, at gas kan anvendes til at gennemføre tjenestehandlinger, der gøres passiv modstand mod, uden krav om at den pågældende tjenestehandling er uopsættelig og uden det først skal vurderes, at mindre indgribende magtmidler er åbenbart uegnede.

De retlige betingelser for brug af tåregas er således en anelse lempeligere end for brug af stav og hund (og for peberspray, jf. afsnit 4.5.2. nedenfor).

Tåregas er umiddelbart det magtmiddel, der er mest beslægtet med peberspray. Men peperspray adskiller sig fra gas ved, at det - ligesom stav og hund bruges direkte mod enkeltpersoner, og ikke - som gas - mod en større ubestemt mængde personer. Den retlige regulering af politiets brug af peberspray er derfor indentisk med reguleringen af stav og hund. På den baggrund forekommer det mest relevant at sammenligne de retlige betingelser for politiets brug af peberspray med de retlige betingelser for politiets brug af stav og hund.

\subsubsection{Specifikke beskyttelsesgarantier før, under og efter brug af stav, hund og gas}

Det følger af politiloven, at politiet inden brug af stav, ${ }^{29}$ hund eller tåregas så vidt muligt skal tilkendegive over for vedkommende, at politiet har til hensigt at bruge det pågældende magtmiddel, såfremt politiets påbud ikke efterkommes. Politiets skal i den forbindelse sikre, at vedkommende reelt har mulighed for at efterkomme politiets påbud. Har politiets brug af stav, hund eller tåregas medført skade skal politiet bistå den skadede person, herunder med adgang til lægetilsyn.

I magtanvendelsesbekendtgørelsen er der yderligere fastsat en række mere specifikke beskyttelsesgarantier for politiets anvendelse af stav, hund og gas.

\section{Anvendelse af stav}

Særligt for så vidt angår politiets anvendelse af stav fremgår det af $\S 12$ i magtanvendelsesbekendtgørelsen, at stav skal anvendes med »besindighed for ikke at påføre nogen større overlast end nødvendigt. « Stav må kun anvendes mod arme, ben, ryg og sæde. Stav må aldrig rettes mod hoved, hals, nakke, kraveben, bryst, mave, nyrer, skridt eller rygsøjle og må ikke bruges til stød.

\section{Anvendelse af hund}

Det fremgår af $\S 17$ i magtanvendelsesbekendtgørelsen, at hund skal anvendes med besindighed, varsomhed og størst mulig skånsomhed. Anvendelsen skal bringes til ophør, når politiets påbud er efterkommet. 


\section{Anvendelse af gas}

Ved anvendelse af gas skal politiet tage hensyn til omfanget af eventuelle gener for udenforstående. Det skal ved denne vurdering bl.a. indgå, om den påtænkte anvendelse af gas vil skulle finde sted i et tættere bebygget område eller nær daginstitutioner, skoler, plejehjem eller lignende. Der skal endvidere tages hensyn til, hvordan vejr- og vindforholdene vil påvirke anvendelsen af gas, jf. § 23, stk. 1. Det præciseres videre i $\S 23$, stk. 3, at politiet skal udvise tilbageholdenhed med at anvende gas over for personer, der befinder sig indendørs. Der skal navnlig tages hensyn til antallet af tilstedeværende personer, samt om det på grund af dårlige adgangsforhold vil være vanskeligt for de pågældende at komme væk fra stedet.

\subsection{Peberspray}

\subsubsection{Indførelsen af peberspray som nyt magtmiddel}

Der blev i juni 2006 indledt et forsøg med anvendelsen af peberspray i tre politikredse. Forsøget blev evalueret af Rigspolitiet i januar 2007.

Det anføres i evalueringsrapporten, at alle tre politikredse overordnet havde en meget positiv vurdering af peberspray.

For så vidt angår pebersprays placering $\mathrm{i}$ »magtbarometeret« anføres på s. $7 \mathrm{i}$ evalueringsrapporten, at de involverede politifolk blev spurgt om:

»hvor de så pebersprayen i forhold til de andre tekniske magtmidler: talens brug, håndkraft, staven og pistolen. Gennemsnitligt angives pebersprayen til at ligge i den øverste ende af håndkraft og i den nederste til midterste del af stavens brug. ${ }^{30}$ (kursiv tilføjet).

Det konkluderes imidlertid på s. 13 i evalueringsrapporten, at:

»i samspillet med de øvrige magtmidler, kan det konstateres, at det [peberspray, red.] naturligt indgår i den øverste ende af talens brug og i den nederste til midterste ende af stavens brug. $\ll^{31}$ (kursiv tilføjet).

Som det fremgår, var det de involverede politifolks opfattelse, at peberspray kunne indplaceres i den »øvre del af håndkraft«, men det konkluderes i rapporten, at peberspray indgår i den »øverste ende af talens brug«. Konklusionen lægger således op til, at peberspray kan erstatte mindre indgribende magtmidler (»talens brug «), end det forudsættes af de involverede politifolk (»håndkraft «).

Vedrørende udsigten til at peberspray kan begrænse politiets brug af øvrige magtmidler konkluderes det: 
»At peberspray er et velegnet teknisk magtmiddel, at det ved en indførelse som supplement til stav, gas, hunde og pistol kan medvirke til, at der sker færre skader på både borgere og politifolk under anholdelser, idet voldsomme anholdelser med for eksempel anvendelse af staven i større omfang kan undgås. $\ll^{32}$

Rigspolitiet var enig i den positive vurdering af peberspray som nyt magtmiddel for dansk politi og indstillede i juni 2007 til Justitsministeriet, at peberspray indføres som et nyt fysisk magtmiddel i dansk politi.

Indstillingen blev tiltrådt af Justitsministeriet, der i september 2007 sendte et udkast til ændring af bekendtgørelse om politiets anvendelse af visse magtmidler m.v. fra 2004 til høring hos relevante myndigheder og organisationer. ${ }^{33}$

Ved den nye magtanvendelsesbekendtgørelse, der trådte i kraft den 1. januar 2008, blev $\S 25$ a-d, om anvendelse af peberspray indsat i bekendtgørelsen.

I tillæg til magtanvendelsesbekendtgørelsen har Rigspolitichefen udstedt en kundgørelse om politiets anvendelse af peberspray. ${ }^{34}$ Kundgørelsen gengiver de almindelige betingelser for politiets magtanvendelse i politiloven ( $\S \S 15-16)$, samt $§ 25$ a-d, i magtanvendelsesbekendtgørelsen. Derudover indeholder kundgørelsen i $\S \S 9-10$ regler om politiets indberetning, registrering og opbevaring af peberspray.

\subsubsection{I hvilke situationer kan politiet anvende peberspray (indikationsgrundene) og under hvilke beskyttelsesgarantier}

Politiets brug af peberspray er reguleret i $\S 25$ a i magtanvendelsesbekendtgørelsen. Betingelserne (indikationsgrundene) for at anvende peberspray er i al væsentlighed identiske med betingelserne for at anvende stav og hund. ${ }^{35}$

Særligt i forhold til politiets brug af peberspray mod personer, der gør passiv modstand mod en tjenestehandling, fremgår det af $\S 25 \mathrm{a}$, nr. 6, at tjenestehandlingen skal være uopsættelig, samt at anden og »mindre indgribende magtanvendelse skønnes åbenbart uegnet.«

Ved brug af peberspray mod personer, der gør passiv modstand, forudsættes det således - ligesom tilfældet er for stav og hund - at politiet inden anvendelsen af peberspray i den enkelte situation konkret vurderer, i) at tjenestehandlingen er uopsættelig; og ii) at mildere magtmidler, dvs. håndjern, håndkraft og talenes kraft, er »åbenbart uegnede.«

Der opregnes videre i magtanvendelsesbekendtgørelsen visse beskyttelsesgarantier før, under og efter brug af peberspray. Politiet skal før brug af peberspray så vidt muligt tilkendegive over for vedkommende, at politiet har til hensigt at bruge peberspray, hvis ikke politiets påbud efterkommes. Politiet skal endvidere 
så vidt muligt sikre, at vedkommende har mulighed for at efterkomme påbuddet, jf. $\S 25$ b.

Har politiets brug af peberspray mod en person medført gener, der skønnes at kræve lægehjælp, skal den pågældende straks undersøges af en læge, jf. § 25 b.

Det er særligt fastslået for peberspray, at politiet efter anvendelse af peberspray i fornødent omfang skal tilbyde at afhjælpe gener forårsaget af, at en person har været eksponeret for peberspray. Det foregår i praksis typisk ved skylning af øjne med vand.

\section{Hvad siger menneskerettighederne?}

Flere menneskeretlige organer har været kritiske overfor brugen af peberspray. Særligt brugen af peberspray i lukkede rum og brugen af peberspray over for personer, der allerede er under kontrol er blevet kritiseret. I det følgende præsenteres et generelt overblik over den menneskeretlige regulering og de vigtigste anbefalinger. Den Europæiske Menneskerettighedskonvention (EMRK) indeholder en række bestemmelser, som er af betydning for nationale myndigheders magtanvendelse, herunder for politiet. Navnlig forbuddet mod tortur, umenneskelig og nedværdigende behandling i artikel 3 er relevant i forhold til politiets magtanvendelse.

Den Europæiske Menneskerettighedsdomstol (EMD) har indtil nu behandlet fem sager om politiets brug af peberspray. Fire sager vedrører Tyrkiet og drejer sig om politiets brug af peberspray (eller tåregas) i forbindelse med demonstrationer. En sag vedrører Ungarn og politiets brug af peberspray i forbindelse med en anholdelse ved en privat fest. EMD har endvidere behandlet en sag vedrørende Estland og fængselspersonalets brug af peberspray mod en aggressiv og farlig indsat. I alle sagerne er peberspray blevet anvendt $\mathrm{i}$ kombination med anden magtanvendelse. Domstolen har ved vurderingen af peberspray lagt vægt på følgende kriterier:

- Den sprayede persons opførsel - udgjorde vedkommende en trussel mod den offentlige orden, mod politiet eller andre?

- Politiets opførsel, herunder om politiet har handlet med tolerance og tilbageholdenhed (»tolerance and restraint «) inden og under brug af peberspray

- Om der har været klare, detaljerede og bindende retningslinjer for politiets anvendelse af peberspray

- Peberspray må ikke benyttes mod personer, som politiet har kontrol over 
- Peberspray må ikke anvendes i lukkede rum (»confined spaces«), hvis alternative magtmidler, blandt andet skjold, beskyttelsesdragt, hjelme mv., kunne være anvendt.

Udover EMRK er FN's Handicapkonvention også relevant i forhold til politiets brug af peberspray. Af Handicapkonventionen følger det, at personer med handicap, herunder psykisk syge har ret til tilpasning i rimeligt omfang, så der bliver taget hensyn til deres særlige behov. Forbuddet mod diskrimination betyder, at det kan være påkrævet at tage særlige hensyn til personer med psykisk sygdom, herunder at sikre, at politiet har den rette viden og personalemæssige ressourcer til at forebygge eskalering af konflikter med personer med psykisk sygdom.

Ud over de nævnte konventioner er udtalelser fra internationale besøgsorganer også relevante i forhold til vurderingen af peberspray i Danmark. Det drejer sig især om udtalelser fra Den Europæiske Torturkomité (CPT). CPT har udtalt, at peberspray ikke bør anvendes i lukkede rum, at der bør være klare retningslinjer for brugen af peberspray, og at peberspray aldrig må anvendes mod en person under kontrol. I følge CPT må peberspray herudover kun bruges på hospitaler $\mathrm{i}$ livstruende situationer. CPT fastslår endelig, at der altid skal være passende afrapportering og kontrol med brugen af peberspray, og at politiet skal være uddannet $\mathrm{i}$ brugen af det.

\section{Sager fra Politiklagemyndigheden}

Politiklagemyndigheden har flere gange kritiseret politiets brug af peberspray og har også i 2013 et særligt afsnit i deres årsberetning om politiets brug af peberspray.

Under henvisning til bl.a. Sundhedsstyrelsens anbefalinger som nævnt indledningsvist, anfører Politiklagemyndigheden, at brug af peberspray bør begrænses mest muligt. Politiklagemyndigheden skriver således, at:

»Politiets anvendelse af peberspray bør [...] begrænses mest muligt under hensyn til, at der er tale om et magtmiddel udviklet med henblik på at påføre fysisk smerte i ikke ubetydelig grad. Brug af peberspray skal således forbeholdes situationer, hvor der reelt er tale om et alternativ til ligeartede eller mere indgribende magtmidler. ${ }^{36}$

Det anføres videre i årsberetningen, at peberspray som udgangspunkt ikke må anvendes mod en fører af et køretøj, som er i fart: 
»Politiklagemyndigheden har i 2012-13 behandlet tre forskellige sager, hvor polititjenestemænd har anvendt peberspray mod føreren af en knallert eller motorcykel under kørsel med henblik på at bringe personen til standsning. I sagerne var der tale om, at politiet eftersatte den pågældende knallertkører eller motorcyklist i anledning af en overtrædelse af færdselsloven. Efter Politiklagemyndighedens opfattelse må eksponering med peberspray af føreren af et køretøj - herunder for eksempel en knallert eller motorcykel - mens køretøjet er i fart, antages at indebære en nærliggende risiko for, at føreren umiddelbart ved eksponeringen mister muligheden for at føre køretøjet på forsvarlig vis. Afhængig af de nærmere konkrete omstændigheder, herunder køretøjets hastighed, vejforholdene på stedet, tilstedeværelsen af andre trafikanter mv., vil en sådan brug af peberspray således medføre betydelig fare for, at føreren af køretøjet samt eventuelle passagerer eller udenforstående personer kommer alvorligt til skade. Brugen af peberspray kan under disse omstændigheder derfor normalt ikke anses for at opfylde kravet i politiloven om magtanvendelsens forsvarlighed. Det er på den baggrund Politiklagemyndighedens opfattelse, at peberspray som udgangspunkt ikke er et egnet magtmiddel i disse tilfælde, hvor føreren af et køretøj i fart ønskes bragt til standsning. $\ll^{37}$

Endelig fastslår Politiklagemyndigheden i årsberetningen, at peberspray ikke må anvendes mod en person, som er under politiets kontrol:

»Når politiet har ilagt en person håndjern, vil vedkommende have meget begrænsede muligheder for for eksempel at gøre aktiv modstand. Der er således en formodning for, at den pågældende person er under politiets kontrol, når vedkommende er ilagt håndjern med begge hænder på ryggen. Hvis den (delvist) pacificerede person alligevel gør aktiv eller passiv modstand, er der tilsvarende en formodning for, at anden mere skånsom magt i situationen vil være tilstrækkelig. [...] Afhængig af de nærmere konkrete omstændigheder - for eksempel en situations særligt tumultariske præg sammenholdt med antallet af tilstedeværende polititjenestemænd - kan der undtagelsesvis være tilfælde, hvor en person, der til trods for, at vedkommende er ilagt håndjern, alligevel ikke er under politiets fulde kontrol. I sådanne tilfælde må mindre indgribende magtanvendelse konkret skønnes uegnet, før politiet kan anvende peberspray.«

Sammenfattende kan det fremhæves, at Politiklagemyndigheden har fastslået, at:

- Politiets brug af peberspray bør begrænses mest muligt.

- Peberspray skal forbeholdes situationer, hvor der reelt er tale om et alternativ til ligeartede eller mere indgribende magtmidler.

- Peberspray må som udgangspunkt ikke anvendes mod en fører af et køretøj, som er i fart.

- Peberspray må ikke anvendes mod en person, som er under politiets kontrol. 


\section{Politiets brug af peberspray i praksis}

For at få et indtryk af, hvordan politiets brug af peberspray ser ud i praksis, har Instituttet som nævnt indledningsvis gennemgået 161 sager fra en udvalgt politikreds, der dækker kredsens samlede brug af peberspray i 2012. Vi har herudover interviewet 19 politibetjente og enkelte repræsentanter fra Rigspolitiet.

\section{Situationer med afvargelse af angreb og fare}

Det er som beskrevet indledningsvist tilladt at bruge peberspray i situationer, hvor politiet afværger et angreb på en person eller afværger en fare for personers liv eller helbred. Gennemgangen af de 161 sager viser, at politiet i 70\% af tilfældene indikerer, at den person, sagen omhandlede, var voldelig. Ser man på de hændelsesbeskrivelser, som politiet har foretaget på hver sag, er konkrete fysiske »angreb« på politiet nævnt i 15 procent af sagerne. ${ }^{38}$ I sagerne er der således eksempler på, at en gerningsmand slår ud efter, gør »fremfald«, sparker eller skubber politiet. Herudover er der eksempler på, at ting bliver kastet mod politiet.

Et eksempel på en sag ser ud som følger:

28/1: En person, der skal anholdes for tyveri, gør udfald mod en betjent og hæver to ølflasker op over sit hoved. Betjenten opfatter dette som en klar trussel mod hans person og tildeler derfor personen peberspray. Herefter taber personen ølflaskerne på gulvet og falder til ro, hvorpå en anholdelse kan gennemføres.

I samtalerne med betjente angiver cirka halvdelen af de interviewede, at de har anvendt peberspray i situationer, hvor de er blevet angrebet fysisk. ${ }^{39}$ En betjent oplevede for eksempel, at en person gemte sig bag en gavl og efterfølgende »sprang på ham« (IP 19), og en anden fortalte, hvordan en person i detentionen sparkede ud efter ham, da han forsøgte at få ham til at aflevere en hashklump (IP 16). Herudover er der eksempler på, at personer har »skubbet«, »slået ud efter betjenten« eller foretaget forskellige former for udfald. En betjent fortæller herudover om en situation, hvor politiet er blevet tilkaldt for at assistere med en bæltefiksering på en psykiatrisk afdeling, hvor patienten »tændte af«, kastede en skraldespand efter politimandens ansigt og angreb hans kollega med spark og slag, hvorefter begge betjente gav patienten peberspray (IP 6).

Gennemgangen af sagerne i den udvalgte politikreds viser herudover, at peberspray ofte anvendes, når de implicerede har en truende adfærd. Disse sager udgør cirka 30 procent af politiets indberetninger. Truslerne er både verbale og fysiske eller kan tage form af aggressivt kropssprog. I sagerne er der eksempler 
på, at en person kommer truende frem mod patruljen, en ophidset ung mand, der slår ud med armene og siger til patruljen, at de »bare kan komme an«, og en person, der slår med knyttet hånd ned i patruljebilens tag. Herudover gives peberspray mod en person, der tager fat om en betjents håndled. I 7 procent af sagerne er den implicerede udelukkende verbalt truende.

Interviewene med betjente bekræfter, at der er en række situationer, hvor politiet føler sig truet uden at blive angrebet fysisk. Der er desuden flere situationer, hvor politiet har anvendt peberspray, fordi de frygtede, at personen, de stod over for, havde et våben eller var ved at skaffe sig adgang til et.

\section{Brug af peberspray ved selvskadende adferd}

Gennemgangen af den udvalgte politikreds' 161 indberetninger viser, at der kun er enkelte sager (5), der omhandler afværgelse af selvskadende adfærd. Peberspray anvendes, enten fordi den implicerede truer med selvmord eller selvbeskadigende adfærd eller skader sig selv i den konkrete situation. Alle sagerne falder i kategorien »at afværge overhængende fare for personens liv eller helbred«, hvilket fremgår af indberetningsskemaet.

Et eksempel på en sag ser ud som følger:

143/12 En psykisk syg mand truer med selvmord med en kniv. Da han ikke vil lægge kniven fra sig, eksponeres han for peberspray. Herefter bliver han kørt til psykiatrisk skadestue.

Kun én af de interviewede betjente har anvendt peberspray for at forhindre selvskadende adfærd. En betjent siger om anvendelsen af peberspray mod en mulig psykisk syg kvinde:

»Jamen jeg har prøvet [det] en gang med én, jeg ved ikke, om hun er psykisk syg, eller hvad hun var, eller i hvert fald påvirket af alt muligt, og sidder og skærer sig selv i armen [...] Og da vi så gik hen til hende, så vendte hun pludselig ud mod os i stedet for [...]. Der er peberspray rigtig effektivt; at man kan stå to meter væk, og så kan man håndtere hende på den måde, så hun bagefter smider det, hun har i hænderne.« (IP 10)

\section{Situationer med anholdelse}

I hovedparten af sagerne (73 procent), hvor peberspray anvendes, sker der anholdelse. I størstedelen af de sager, hvor der er sket anholdelse, anvendes peberspray, fordi personen opfører sig truende i situationen (som også beskrevet overfor). ${ }^{40}$ 
I indberetningerne beskrives personerne for eksempel som »verbalt truende og ophidset«, »højrøstet og aggressiv«, »truende kropssprog« og/eller »fysisk aggressiv«. Truende kropssprog beskrives for eksempel som, at personen »hæver begge arme«, »slår ud med« eller »fægter med armene«. Herudover er der flere eksempler på, at personerne går eller løber frem mod politiet eller vender sig om mod politiet.

Deciderede angreb på politiet $\mathrm{i}$ anholdelsessituationen fremstår mindre udbredt, men optræder som nævnt også. Det anføres for eksempel i enkelte indberetninger, at personer havde »opført sig voldeligt«, »havde slået ud efter politiet«, skubbet eller sparket politiet.

Sagerne viser ydermere, at peberspray anvendes, når personerne forsøger at rive sig fri fra betjentens greb, gør modstand mod at blive i lagt håndjern eller blive lagt ned. Herudover bruges peberspray også, når en person forsøger at undslippe politiet eller ikke vil følge med. Der er her flere eksempler på personer, der ikke kategoriseres som voldelige.

Gennemgangen af sagerne viser endelig også, at peberspray anvendes, når andre forsøger at forhindre en anholdelse, for eksempel ved at blande sig i anholdelsen eller ved at prøve at få fat $\mathrm{i}$ anholdte. I nogle af tilfældene er de pågældende truende eller slår ud efter politiet. I andre situationer nægter de enkelte at forlade et sted eller adlyde betjentens ordrer, men er ikke truende.

To eksempler på indberetninger om brug af peberspray i forbindelse med anholdelse ser ud som følger:

55/12 I forbindelse med, at en person ikke ønsker at oplyse navn, fødselsdag og adresse til en patrulje, anholdes han. Under anholdelsen gør han modstand ved at slå og sparke ud mod patruljen, hvorfor politiet benytter peberspray. Herefter kan gerningsmanden følges til patruljebilen.

22/12: Efter endt eftersættelse af en person i et brugsstjålet køretøj modsætter denne sig anholdelse. Da personen nægter at stige ud af bilen, eksponeres han for peberspray. Pebersprayen skønnes dog ikke at have nogen effekt, da han ikke bliver ramt i øjnene. Personen bliver herefter anholdt af flere tilstedeværende politifolk.

Nogle af de interviewede betjente har også anvendt peberspray i forbindelse med anholdelse. Dette begrunder de primært med, at den eller de implicerede var aggressive og/eller truende eller på anden vis gjorde modstand mod anholdelsen. En betjent fortæller for eksempel om en ung diskoteksgæst, der ikke ville forlade di- 
skoteket og var »beruset og aggressiv« (IP 13) og gjorde aktiv modstand mod anholdelsen ved blandt andet at tage fat i betjenten. En anden fortæller om en situation, hvor hans kollega »stod og bøvlede med en, der ikke vil lade sig anholde« (IP 18), og brugte peberspray for, ifølge betjenten, at undgå skade på den anholdte såvel som på betjentene selv.

Betjentene nævner herudover brug af peberspray, når personer, der blander sig i anholdelsen, skal holdes væk. En betjent fortæller om behovet for at holde omkringstående væk i nogle situationer:

»[Det kan være] en, der har været voldelig, eller to, der har været i et slagsmål, hvor den ene skal anholdes, og vi går hen for at anholde ham, og så er der tit det, at hans kammerater [...] ikke finder sig i det og prøver at befri ham eller beskytte ham mod at blive anholdt. Der er det effektivt at få folk væk, for ikke at komme til skade.« (IP 9)

Samtidig er der eksempler på situationer, hvor betjenten bruger peberspray både for at holde omkringstående på afstand, og fordi personen modsætter sig anholdelse. En betjent fortæller:

»[Jeg gav ham peberspray] fordi han prøver at vride sig løs, så jeg tænker, at det er jo svært både at holde ham og så holde de andre på afstand på én gang; de skal jo hen og befri ham. Så der får han så noget peber. [...] Vi kommer jo mere eller mindre i slagsmål. Ikke sådan at han nødvendigvis prøver at slå mig, men han prøver i hvert fald at rive sig fri og alt det der. Så der får han peber.«(IP 16)

\section{Gadeslagsmål og slagsmål i forbindelse med fodboldkampe}

Gennemgangen af sagerne fra den udvalgte politikreds viser, at der er 11 sager ud af 161, hvor peberspray er blevet anvendt i forbindelse med uroligheder, der opstår i kølvandet af fodboldkampe. ${ }^{41}$ Herudover er der 43 sager, der involverer slagsmål, hvor politiet vil bringe slagsmålet til ophør og/eller skille mængden ad. Peberspray bruges for at få de implicerede til at følge deres anvisninger, for eksempel at gå væk fra stedet, eller til at få folk, der blander sig, til at gå væk. Der er her både sager, hvor de implicerede karakteriseres som voldelige, og sager, hvor der ikke er tale om voldelige personer. Peberspray benyttes både over for enkeltpersoner og ind i en større gruppe.

I det følgende gives to eksempler på indberettede sager, der falder i denne kategori: 
6/12 I forbindelse med sigtelse af en gerningsmand kommer flere personer truende frem mod patruljen. Disse advares om brugen af peberspray og bliver bedt om at gå væk. Da de igen kommer frem mod patruljen, bliver de eksponeret for peberspray. Dette sker for at skabe arbejdsro og for at afværge et angreb på patruljen. Flere personer rammes af skyen fra pebersprayen.

27/12 Op mod 40 personer var i tumult. To personer forsøger at forhindre politiets intervention. De to personer blev først bedt verbalt om at gå fra stedet og efterfølgende forsøgt skubbet væk. Den ene person forlod stedet, men den anden fortsatte med at hindre politiet i deres aktiviteter og fik derfor peberspray.

De interviewede betjente har ligeledes brugt peberspray i forbindelse med både gadeslagsmål og tilknytning til fodboldkampe. I forhold til slagsmålene er begrundelserne for brugen af peberspray, at parterne »skal adskilles«, at folk »skal sprede sig«, at de »ikke kunne få folk væk«, og »at de skulle skaffe sig afstand«. Peberspray bliver her både brugt direkte mod enkeltpersoner og ind i en mængde ved at »spraye ud i en sky«. En situation beskrives som følger:

»Jeg kan huske det en gang, [...] hvor vi havde bøvl med [nogle fans]. Hvor det kommer til noget sammenstød, hvor vi ikke kan få folk væk. Og de begynder også at komme imod os og kaste flyvende dåser og sådan noget. $\mathrm{Og}$ der bruger kollegaerne peberspray for at skabe os arbejdsrum, for at få dem til at trække sig tilbage. Det virker sgu rigtig godt på dem, der bliver ramt, men hvis de løber, så løber de andre som regel også.« (IP 6)

En anden siger om en situation med nogle fans: »Jeg har ikke rigtig nogen idé om, om nogen blev ramt decideret. Det var mere sådan en 'nu skal vi have skaffet afstand-ting'.«(IP 2)

\section{Passiv modstand}

Det er efter loven tilladt at bruge peberspray i situationer, hvor der ydes passiv modstand mod politiet. Tjenestehandlingen skal skønnes uopsættelig, og anden og mindre indgribende magtanvendelse skal være uegnet.

En gennemgang af sagerne fra politikredsen viser, at peberspray er blevet anvendt 11 gange, hvor begrundelsen er passiv modstand.

Den passive modstand er fortrinsvis udøvet af enkeltpersoner. Fælles for sagerne er, at personen ikke vil følge politiets anvisninger. I cirka halvdelen af sagerne anvendes peberspray, fordi personen enten ikke vil forlade stedet eller ikke vil stå ud af sin bil. Herudover anvendes peberspray i forbindelse med, at perso- 
nen modsætter sig at blive ilagt håndjern ved at holde armene fast ind til kroppen. I fire sager er der tilsyneladende ikke frygt for vold eller lignende, og den enkelte person modsætter sig politiet på fredelig vis. Tre af sagerne involverer psykisk syge. Der er dels tale om en person, der ikke vil lade sig bæltefiksere, og dels en person, der truer med at gøre skade på sig selv. Herudover er der et eksempel på en person, der er trængt ind i en ældre dames lejlighed (hvor han tager et bad) og nægter at forlade damens lejlighed. I sagsbeskrivelserne fremgår det ikke nærmere, hvorfor tjenestehandlingerne er skønnet uopsættelige, og hvorfor anden og mindre indgribende magtanvendelse er uegnet. Dette er ikke spørgsmål, betjentene bedes om at besvare $\mathrm{i}$ indberetningsskemaet.

En sag ser ud som følger:

22/11 En person er blevet eftersat på grund af tyveri og gør modstand mod at komme ud af bilen. Herefter anvendes peberspray, og personen anholdes.

Der er ikke nogen af de interviewede betjente, der har anvendt peberspray i situationer, de har kategoriseret under »passiv modstand«. Betjentene har imidlertid givet tænkte eksempler på, i hvilke situationer peberspray ville blive anvendt, hvis der var tale om passiv modstand. Her blev nævnt, at peberspray ville kunne bruges i forbindelse med »sit-down«-demonstrationer på gaden, hvor folk ikke ville fjerne sig, eller andre lignende demonstrationer. Herudover kan peberspray tænkes anvendt $\mathrm{i}$ andre situationer, hvor folk ikke vil fjerne sig. Betjentene nævner eksempler som, at »en person holder fast i en bildør og ikke vil give slip« (IP 13), en mand, der efter et husspektakel spærrer udgangen, så politiet ikke kan komme forbi med en tilskadekommen (IP 12), eller omkringstående personer, der ikke vil fjerne sig i forbindelse med en anholdelse (IP 8). Peberspray kan ydermere anvendes, når en person ikke vil følge med betjenten. En betjent beskriver, hvordan en situation kunne se ud, når en person ikke vil adlyde betjentens ordre:

»Vi har jo folk, der bare står og siger: 'Hvis I kommer tæt på, så smadrer jeg jer. Jeg skal ikke med på stationen.' Og så siger man: 'Jamen vi gider ikke slås med dig.' For så skal vi bruge staven mod ham, eller også skal vi være mange til at krølle ham sammen. Så er det bare at give ham noget peber.« (IP 16)

Flere betjente siger dog, at der skal være tale om en tilspidset situation, før de vil anvende peberspray i forbindelse med passiv modstand. En betjent siger for eksempel: 
»Hvis folk har lagt sig og nægter at flytte sig, kan man give dem peberspray og få dem væk. Jeg ved ikke, om jeg ville gøre det. Der er altid en grænse i forhold til at yde magt på folk, der teknisk set ikke gør noget.« (IP 14)

\section{Persongrupper, der scerligt udscettes for peberspray}

Ifølge Rigspolitiets statistik over brugen af peberspray på landsbasis bliver peberspray ofte brugt over for berusede og narkotikapåvirkede personer. I $2012 \mathrm{blev}$ peberspray således anvendt mod berusede og narkotikapåvirkede personer i henholdsvis 57 procent og 21 procent af tilfældene. Fordelingen ser ud som følger:

Tabel 3. Fordeling af indberetninger om brug af peberspray, hvor scerlige personlige forhold gør sig geeldende for den ramte person (landsstatistik 2012)

\begin{tabular}{ll}
\hline Beruset person & $57 \%$ \\
\hline Narkotikapåvirket person & $21 \%$ \\
\hline
\end{tabular}

I den udvalgte politikreds er tallene lidt højere og ser her ud som følger: ${ }^{42}$

Tabel 4. Fordeling af indberetninger om brug af peberspray, hvor scrlige personlige forhold gør sig galdende for den ramte person (udvalgt politikreds $i$ 2012)

\begin{tabular}{ll}
\hline Beruset person & $69 \%$ \\
\hline Narkotikapåvirket person & $30 \%$ \\
\hline
\end{tabular}

De interviewede betjente har anvendt peberspray over for personer, der er påvirket af enten narkotika eller alkohol, hvilket de opfatter som relativt ofte forekommende. Der tales om situationer, hvor de implicerede har været udadreagerende og ikke til at tale med. En betjent siger:

Vi bruger tit peberspray mod personer, der er mentalt ustabile [...] typisk folk, der har taget amfetamin eller kokain. Ofte er de uden samarbejdsvilje overfor politiet. De er opfarende og stærke og lader sig ikke påvirke, selvom de bliver udsat for smerte.« (IP 15)

Anvendelsen af peberspray mod psykisk syge udgør også et anseeligt antal i politiets statistikker. Ifølge politiets opgørelser blev peberspray anvendt mod en psykisk syg person i 2012 i $15 \%$ af samtlige de indberettede sager i hele Danmark. I 
den udvalgte politikreds er billedet det samme med anvendelse af peberspray mod psykisk syge i $14 \%$ af tilfældene. Sagerne i politikredsen omfatter blandt andet brug af peberspray i forbindelse med bæltefiksering ( 2 sager) og forhindring af selvskadende adfærd (5 sager). Herudover anvendes peberspray ved truende og voldelig adfærd.

Brugen af peberspray mod psykisk syge er et tema, der går igen i interviewene. Peberspray bruges for eksempel, når politiet tilkaldes for at hjælpe med håndtering af psykisk syge på hospitaler. Herudover er der et eksempel på en psykisk syg mand, som ikke ville lade sig indlægge og spærrede sig inde i sit hus, samt en psykisk syg kvinde, der forsøgte at køre ind i politiet. Ifølge politiet er der udviklet et særligt koncept med brug af skum i forbindelse med håndtering af psykisk syge, som kan anvendes i stedet for peberspray. Interviewene viser, at betjentene har brugt skum i enkelte tilfælde, men at peberspray, som nævnt overfor, også anvendes. Når peberspray tages i brug mod psykisk syge kan det ifølge en betjent blandt andet være, fordi det er vanskeligere at tale med disse mennesker. En betjent siger, at »det er et problem, hvis man ikke føler man kan snakke fornuft med ham« og at »man ikke kan sige til en [psykisk] syg person, at han skal 'slappe af' " (IP 19). Manglen på konstruktiv dialog kan således føre til magtanvendelse. En betjent udtaler:

»Oftest lykkes det at tale dem ud af det og nogle gange er de også helt fornuftige, det er slet ikke det. Men de er utilregnelige, og det er jo derfor, man bruger os i de her sager.« (IP 6)

I forhold til brugen af peberspray $\mathrm{i}$ forbindelse med håndtering af psykisk syge har Rigspolitiet oplyst, at »politiet som udgangspunkt ikke vil anvende magt over for psykisk syge. Der kan dog opstå situationer i forhold til politiets håndtering af psykisk syge, hvor anvendelsen af magt er nødvendig og forsvarlig. I sådanne tilfælde vil det bero på en konkret vurdering, hvilket magtmiddel der er mest skånsomt i forhold til den konkrete situation. $\ll^{43}$

\section{Steder, hvor peberspray anvendes}

Politiets statistik viser, at peberspray overvejende anvendes på gaden. Dette forekommer i 59 procent af tilfældene. Sagerne fordeler sig som illustreret nedenfor. 
Tabel 5. Antal indberetninger om brug af peberspray opdelt efter stedet for brugen (2012, landsstatistik)

\begin{tabular}{lr}
\hline Anvendt i/ved bolig & $19 \%$ \\
\hline Anvendt i/ved værtshus & $5 \%$ \\
\hline Anvendt i/ved gade & $59 \%$ \\
\hline Anvendt offentlige steder & $17 \%$ \\
\hline
\end{tabular}

Anvendelse af peberspray inden døre og i lukkede rum

Gennemgangen af sagerne i politikredsen viser, at peberspray blev anvendt indendørs i 30 procent af tilfældene. I 23 af disse sager sker anvendelsen i et lukket/afgrænset rum, herunder køkkener, badeværelser, værelse på et hospital, detention mv. I sagerne indgår herudover 7 tilfælde, hvor peberspray bruges i en patruljebil, og 3 sager, hvor det anvendes i en personbil. Sagsfordelingen ser ud som følger:

Tabel 6. Antal indberetninger om brug af peberspray fra udvalgt politikreds (2012)

\begin{tabular}{lc}
\hline Anvendt indendørs & 48 sager (30 \%) \\
\hline Anvendt i lukkede rum & 23 sager (14 \%) \\
\hline Heraf patruljebil & 7 sager (4 \%) \\
\hline Heraf i personbil & 3 sager $(2 \%)$ \\
\hline
\end{tabular}

Peberspray anvendes typisk i patruljebilen i tilfælde, hvor personen gør modstand i bilen. Herudover vil en impliceret $i$ en enkelt sag ikke følge betjentenes ordre om at sætte sig i bilen.

Peberspray anvendes også i sjældne tilfælde i personbiler, primært fordi den implicerede ikke vil stå ud af bilen. ${ }^{44}$

De interviewede betjente har både anvendt peberspray i en detention, i en togkupé, i en patruljevogn og på et diskotek. Herudover er der eksempler på anvendelse af peberspray i private hjem. En betjent fortæller om anvendelsen af peberspray i en patruljebil, fordi den anholdte var voldelig:

»Han sparkede og prøvede at sparke vinduerne ud og kom ned og ligge og lå og sparkede på ham, der sad på bagsædet sammen med ham [...] Strålen ramte lige i panden på vedkommende.« (IP 9) 
Som nævnt indledningsvis har menneskeretlige organer stillet sig kritiske over for brugen af peberspray i lukkede rum. De interviewede betjente er derfor i forbindelse med undersøgelsen blevet spurgt, om de gjorde sig nogen særlige overvejelser i forbindelse med brugen af peberspray i lukkede rum.

Ifølge betjentene er den største ulempe, at politiet selv kan blive eksponeret for peberspray, ligesom eventuelle andre, som ikke er involveret i episoden, kan blive det. En betjent siger:

»[...] Det er heller ikke taktisk særlig smart at gøre det på bagsædet af en patruljebil for eksempel, for så kan man stort set ikke sidde i patruljebilen bagefter, kan man sige. Man kan blive ... Så bliver man nødsaget til det nogle gange simpelthen, for at altså det er det mildeste magtmiddel, men taktisk er det ikke særlig smart. I små rum.« (IP 2)

Det forhold, at peberspray også vil virke mere kraftigt på den eksponerede i lukkede rum, er dog ikke et forhold, som de interviewede betjente har nævnt som en faktor af betydning. Det afgørende er hensynet til politiet selv og eventuelle uskyldige.

Steder og situationer, hvor peberspray er mindre egnet

Ifølge betjentenes udtalelser er der særlige situationer og steder, hvor peberspray er et mindre velegnet magtmiddel. Der er lokaliteter, hvor brugen af peberspray kan skabe en farlig situation for den berørte. Dette kan for eksempel være, hvis der er risiko for, at personen, der får peberspray, risikerer at pådrage sig en skade. Det kan blandt andet være uhensigtsmæssigt at anvende peberspray på en motorvej, på tribunen på et stadion, på togstationer, eller hvis den udsatte person kører knallert. Hertil kommer situationer, hvor uskyldige vil blive ramt af pebersprayen. Dette kan for eksempel være en risiko på et diskotek, i en togkupé, i en bus eller i større forsamlinger. I interviewene nævnes det også, at betjentene ønsker at undgå, at de selv eller kollegaerne bliver udsat for peberspray. Dette kan for eksempel være tilfældet, hvis midlet anvendes i små rum, for eksempel bagsædet på en bil, udenfor med en forkert vindretning eller i større forsamlinger.

Peberspray kan ifølge politiet ydermere være uegnet i situationer, hvor en sanering (at skylle personens øjne) efterfølgende vil have været for tidskrævende. Der er således i nogle situationer ikke altid ressourcer til, at politiet kan sanere, hvis situationen i øvrigt ikke er under kontrol. 
Anvendelsen fordelt over døgnet

Politiets statistik viser, at peberspray oftest anvendes i nattelivet, hvilket også afspejles i betjentenes udtalelser. Sprayen bruges således hyppigst i tidsrummet mellem kl. 23 om aftenen og 7 om morgenen. Tallene ser ud som følger:

\section{Tabel 7. Antal indberetninger om brug af peberspray opdelt efter tidspunktet for brugen (2012)}

\begin{tabular}{ll}
\hline Tidsrum $07-15$ & $13 \%$ \\
\hline Tidsrum $15-23$ & $34 \%$ \\
\hline Tidsrum $23-07$ & $53 \%$ \\
\hline
\end{tabular}

\section{Allerede under kontrol}

Menneskeretlige organer har kritiseret brugen af peberspray over for personer, der allerede er under kontrol. For eksempel er brugen af peberspray mod et menneske, der er lagt $\mathrm{i}$ håndjern, blevet kritiseret (se afsnit 5).

Den Uafhængige Politiklagemyndighed har ligeledes i en konkret sag udtalt, at brug af peberspray over for en person ilagt håndjern var kritisabelt (se afsnit 6).

Gennemgangen af indberetningerne fra den udvalgte politikreds viser, at i de 7 sager, hvor peberspray anvendes $\mathrm{i}$ en patruljebil, er personen ilagt håndjern $\mathrm{i} \mathrm{de}$ $6 .^{45} \mathrm{I}$ alle tilfældene gør personerne fysisk modstand ved at sparke på inventar i bilen, sparke på personalet eller på anden måde opføre sig voldsomt. I en enkelt sag vil en impliceret ikke følge betjentens ordre om at sætte sig i bilen. Personen er ilagt håndjern og vil ikke bukke sig ind i bilen. Han lægges efterfølgende på maven på bagsædet af bilen, men vil ikke bukke benene. Herefter får han peberspray.

Gennemgangen af sagerne viser ydermere, at der er 3 tilfælde, hvor den implicerede $\mathrm{i}$ forbindelse med anholdelsen er blevet lagt ned på jorden af politiet og herefter eksponeres for peberspray. ${ }^{46}$

På baggrund af kritikken mod at bruge peberspray over for personer, der allerede er under kontrol, er de interviewede betjente blevet spurgt, om de ville anvende peberspray i sådanne situationer. Det er konkret sket ved, at betjentene er blevet bedt om at tage stilling til nogle eksempler, der bygger på information fra interviews med 7 indsatte, som instituttet har foretaget.

De interviewede betjente er blevet forelagt et eksempel på en person, der blev udsat for peberspray, mens denne var iført håndjern og sad i en politibil. Herudover er de blevet præsenteret for et eksempel på en person, der ligeledes sad i en 
politibil, men uden håndjern og fik peberspray. Endelig er de blevet bedt om at forholde sig til et eksempel på brug af peberspray på en person, der var lagt på maven og i greb, og som samtidig blev udsat for peberspray.

Ingen af de adspurgte betjente mener, at peberspray bør bruges mod personer, der allerede er under kontrol, og at det i så fald ville have karakter af afstraffelse. Begrebet »allerede under kontrol« er dog et lidt vanskeligt begreb. Ifølge flere betjente er det ikke sikkert, at en person er under kontrol, fordi han har håndjern på. Det er heller ikke sikkert, at en person er under kontrol, selvom vedkommende ligger ned og holdes i et greb.

Politifolkenes betragtninger peger i forskellige retninger, når de spørges ud, om en person, der er iført håndjern og sidder i en politibil, bør udsættes for peberspray.

Flere betjente mener, at det vil være en absolut undtagelse at bruge $\mathrm{i}$ en bil og over for en person, der er iført håndjern. Det vil normalt kun forekomme, hvis personen er meget udadreagerende og for eksempel sparker på chaufføren eller på ruden. Personen skal stadig udgøre en trussel på trods af håndjernene og således ikke være under kontrol. Herudover siger en betjent, at brugen af peberspray også ville kunne retfærdiggøres, hvis personen for eksempel spytter på betjentene, eller hvis alternativet $\mathrm{er}$, at personen skal passiviseres med håndkraft.

Andre betjente mener, at en person i håndjern, der sidder i en politibil, i princippet burde være så meget under kontrol, at situationen vil kunne håndteres med håndkraft. Flere betjente peger ydermere på, at brugen af peberspray over for en person i håndjern i en politibil kan give indtryk af, at politiet »hævner sig«. En betjent siger:

»Jeg synes, hvis vi forestiller os situationen, hvor han sidder - og det kan godt være, at han er møgflabet, og det kan også godt være, at han har spyttet - så vil jeg stadigvæk sige, at det virker mere som sådan en ... en lille hævn, straf-agtig ting: 'Så kan du få den, du spytter på mig, så får du den her af mig.' Men det tror jeg ikke, selv jeg ville gøre.« (IP 2)

I forbindelse med eksemplet, hvor en person får peberspray, mens vedkommende ligger på jorden og er i greb, er der også forskellige holdninger. Flere betjente mener, at når et menneske ligger på jorden i greb, er vedkommende under kontrol. Selvom vedkommende måske er ophidset, vil personen principielt være under kontrol i den position. Brug af peberspray vil således ikke være berettiget. En betjent siger, at »det er begrænset, hvor farlig man er« (IP 19), og en anden, at »har vi dem først nede og ligge, har vi styr på dem« (IP 18). 
Andre betjente mener, at personen kan have en fysik, der gør, at politiet kan have svært ved at kontrollere ham. At han ligger på maven i greb, udelukker for eksempel ikke, at han kan sparke med benene og gøre anden form for modstand, hvilket ville kunne retfærdiggøre brugen af peberspray.

\section{Advarsel mod peberspray}

Ifølge loven skal politiet så vidt muligt tilkendegive over for personen, at de har til hensigt at anvende peberspray. Politiet har ikke samlede statistiske oplysninger på landsbasis over advarsler mod peberspray. En manuel sammentælling af samtlige sager i 2012 i den udvalgte politikreds viser imidlertid, at ud af 161 sager har politiet advaret mod peberspray 123 gange, altså i 76 procent af tilfældene.

Interviewene med betjente viser, at det varierer, hvorvidt der advares mod peberspray. Nogle informanter fortæller, at de aldrig har advaret mod det, andre, at de har advaret i nogle tilfælde, og enkelte, at de ofte har advaret.

Betjentene er bekendt med, at de så vidt muligt skal tilkendegive, at de har til hensigt at bruge peberspray i en given situation. Der er imidlertid flere grunde til, at der ikke altid advares mod brugen af peberspray. En begrundelse er ifølge flere betjente, at situationen opstår meget hurtigt eller har udviklet sig til tumult. En betjent siger for eksempel om brugen af advarsler her:

»Umiddelbart så har jeg ikke advaret en eneste gang. Fordi der ikke har været tid til det, eller det ikke passede ind i situationen. Det var ikke af ond vilje. Jeg tror heller aldrig, at de [andre betjente] advarer. Når det sker, sker det lynhurtigt. Jeg husker ikke situationer hvor kollegaer har råbt: 'Der kommer peberspray.' « (IP 15)

En anden grund til ikke at advare er, at betjenten ønsker at overrumple personen og af denne grund ikke ønsker at advare vedkommende. Der er ifølge betjentene også situationer, hvor en advarsel ikke giver mening. Det kan enten være, fordi advarslen ikke ville kunne høres på grund af støj på stedet, eller fordi den udsatte ikke kan forstå advarslen. En betjent siger for eksempel, at det kan være omsonst at advare én, der er beruset og/eller stofpåvirket eller en udlænding, der hverken forstår engelsk eller dansk (IP 13).

I interviewene nævner betjentene også en række situationer, hvor der er gode grunde til at advare mod peberspray. Dette gælder især, hvor de ser en mulighed for, at advarslen vil virke præventivt - for eksempel at omkringstående vil trække sig væk, hvis de bliver truet med brugen af peberspray.

Flere fortæller, at advarslen kan ske med ord eller ved blot at tage pebersprayen frem. Ifølge interviewmaterialet er advarslen som regel særligt effektiv, hvis 
dem, advarslen er rettet imod, har været eksponeret for peberspray tidligere. En betjent siger, at folk følger advarslen, fordi det er »ydmygende« at blive udsat for peberspray, og andre, at truslen om peberspray kan være nok til at kontrollere en situation (IP 16).

\section{Opsummering}

Indberetningerne og interviewene viser, at politiet typisk anvender peberspray $\mathrm{i}$ situationer, hvor betjente skal overvinde aktiv modstand eller føler sig truet. Typisk sker det under anholdelse og slagsmål. Begrundelsen for anvendelsen er ofte betjentenes egen sikkerhed. Peberspray benyttes dog også over for mennesker, der er verbalt aggressive, men ikke decideret voldelige. Undersøgelsen viser, at peberspray også anvendes for at få en person til at følge politiets anvisninger. Der er i den forbindelse flere eksempler på, at peberspray benyttes, hvor personen er usamarbejdsvillig, men ikke er voldelig (for eksempel en person, der modsætter sig ilæggelse af håndjern, og en person, der forsøger at undslippe politiet). ${ }^{47} \mathrm{Pe}$ berspray anvendes i overvejende grad i tidsrummet kl. 23-07, og de udsatte personer er ofte enten berusede eller narkotikapåvirkede.

Peberspray bruges også, hvor der ydes passiv modstand mod politiet. I sagerne fra den udvalgte politikreds forekommer alene passiv modstand fra enkeltpersoner. Der forekommer ingen sager om passiv modstand fra grupper. I fire af sagerne er der ikke frygt for vold, men personen modsætter sig på fredelig vis. For eksempel bruges peberspray mod én, der ikke vil stå ud af sin bil, og en anden, der ikke vil følge med politiet.

Peberspray benyttes primært udenfor og i mindre omfang indendørs. Der er 23 sager, hvor peberspray anvendes i lukkede rum, for eksempel en detention og et værelse på et hospital. Der er i materialet ti eksempler på, at peberspray enten er blevet brugt $i$ en personbil eller en patruljebil. I seks af disse tilfælde var den implicerede allerede ilagt håndjern.

Betjentenes fortællinger om deres anvendelse af peberspray vidner om, at der er en række pludseligt opståede situationer, hvor magtmidlet bruges. Dette gælder især, når betjente er blevet udsat for vold eller trusler herom. Interviewene peger desuden på situationer, hvor politiet må regne med, at de potentielt vil anvende et magtmiddel. Dette gælder i forbindelse med fodboldkampe, hvor slagsmål er almindeligt forekommende. Det er derfor relevant at spørge, om disse situationer kunne være håndteret anderledes og anvendelsen af magtmidler undgået. Ligeledes når peberspray benyttes i situationer, hvor den implicerede udelukkende er verbalt aggressiv eller ikke vil følge politiets anvisninger uden samtidig at være voldelig, og i situationer, hvor den implicerede allerede er ilagt håndjern, kan 
man spørge, om peberspray kunne være undgået, og om anvendelsen er proportionel. Ikke mindst er disse spørgsmål relevante, da der, som alle de gennemgåede sager viser, kun er involveret enkeltpersoner.

\section{Er danske regler og praksis i overensstemmelse med menneskeretlige krav og anbefalinger?}

Vores undersøgelse viser, at der på en række punkter kan sættes spørgsmålstegn ved, om danske regler og praksis vedrørende brug af peberspray i politiet lever fuldt op til de skitserede menneskeretlige krav og anbefalinger.

\subsection{Politiets vurdering af peberspray}

Internationale menneskerettighedsorganer, herunder EMD og CPT, har fremhævet, at der kan være alvorlige helbredsrisici forbundet med at anvende peberspray, særligt mod personer, som i forvejen lider af luftvejssygdomme.

Tilsvarende har Sundhedsstyrelsen i sin vurdering af peberspray anført, at der kan være alvorlige helbredsrisici forbundet med at blive eksponeret for peberspray. En opfattelse der også kommer til udtryk i Østre Landsret afgørelse om peberspray fra 2010, hvor et civilt angreb med peberspray ansås for omfattet af $\S$ 245 i straffeloven vedrørende vold af »særlig, rå, brutal eller farlig karakter.«

Sundhedsstyrelsen anbefaler på den baggrund, at peberspray kun anvendes til »snævert definerede formål, hvor mindre farlige alternativer ikke foreligger. ${ }^{48}$

Ligeledes anfører Politiklagemyndigheden, at politiets anvendelse af peberspray bør »begrænses mest muligt under hensyn til, at der er tale om et magtmiddel udviklet med henblik på at påføre fysisk smerte i ikke ubetydelig grad«, jf. afsnit 6 ovenfor.

Denne opfattelse af, at peberspray er et potentielt farligt og dermed også alvorligt magtmiddel, genfindes imidlertid ikke i politiets vurdering af peberspray.

Det anføres f.eks. således i Rigspolitiets evalueringsrapport fra 2007, at peberspray i samspillet med de øvrige magtmidler »naturligt indgår i den øverste ende af talens brug og i den nederste til midterste ende af stavens brug.« (kursiv tilføjet).

Undersøgelsen af praksis bekræfter ligeledes, at de interviewede betjente alle opfatter peberspray som et af de mest skånsomme magtmidler, og at peberspray anses for mindre indgribende end hårdhændede greb.

Der synes således at være et misforhold mellem politiets opfattelse af, hvor alvorligt et magtmiddel peberspray er, og andre danske myndigheders og internationale menneskerettighedsorganers opfattelse af magtmidlets tyngde. 
8.2. De retlige betingelser for anvendelse af peberspray og politiets vurderingbruger politiet peberspray for meget?

De retlige betingelser for, i hvilke situationer politiet kan anvende peberspray (indikationsgrundene), er identiske med de retlige betingelser for anvendelse af stav og hund.

Politiet opfatter som nævnt ovenfor peberspray som et af de mest skånsomme magtmidler, der kan anvendes fra »den øverste ende af talens brug og den nederste til midterste ende af stavens brug, « herunder altså også i situationer, hvor politiet kunne have anvendt håndkraft.

Undersøgelsen af praksis, herunder de statistiske oplysninger om politiets brug af peberspray, kan indikere, at politiet anvender peberspray i situationer, hvor der tidligere ville være blevet anvendt håndkraft (eller talens brug).

Det fremgår af de gennemførte interviews, at politibetjentene - i overensstemmelse med Rigspolitiets opfattelse - generelt opfatter peberspray som et mindre alvorligt magtmiddel end håndkraft, og at peberspray i nogle situationer bruges i stedet for fx greb.

Der er imidlertid som beskrevet tidligere væsentlig forskel på de retlige betingelser for, hvornår politiet kan anvende peberspray (magtanvendelse med magtmiddel), og hvornår betjentene kan anvende håndkraft og talens brug (magtanvendelse uden magtmidler). Politiet kan kun anvende peberspray og øvrige magtmidler under skærpede juridiske betingelser. Det kan alene ske under iagttagelse af de seks indikationsgrunde og de specifikke beskyttelsesgarantier.

Politiet kan således altid vælge at bruge håndkraft i form af fx greb eller talens kraft i stedet for peberspray. Men politiet kan omvendt ikke altid vælge at bruge peberspray $\mathrm{i}$ stedet for håndkraft eller talens kraft.

Politiets opfattelse, hvorefter peberspray kan anvendes i stedet for håndkraft eller den »øverste ende af talens brug« er ikke afspejlet i den retlige regulering.

Der synes således at være et misforhold mellem de retlige betingelser for, hvornår politiet kan anvende peberspray, og politiets vurdering af i hvilke faktuelle situationer de kan anvende peberspray. Et misforhold der alt andet lige vil kunne føre til en for udbredt brug af peberspray.

\subsection{Pracisering af indikationsgrundene for at anvende peberspray}

Den Europæiske Menneskerettighedsdomstol og CPT har gentagne gange anført, at der skal være klare, detaljerede og bindende retningslinjer for politiets anvendelse af peberspray.

Politiets brug af peberspray er ikke reguleret i politiloven på lige fod med de øvrige magtmidler, men alene i magtanvendelsesbekendtgørelsen. 
Bemærkningerne til lovforslaget fra 2004 om politiloven indeholder ganske udførlige og præcise retningslinjer for, i hvilke situationer politiet må benytte skydevåben, stav, hund og gas. Det samme er ikke tilfældet for peberspray. De situationer, hvor politiet kan anvende peberspray i $\S 25$ a i magtanvendelsesbekendtgørelsen (indikationsgrundene), er ikke nærmere præciseret eller uddybet i bekendtgørelsen.

Det må imidlertid antages, at bemærkningerne til lovforslag om politiloven fra 2004, herunder navnlig de særlige bemærkninger til politiets brug af stav gengivet i afsnit 4.4.1. ovenfor, også må være retningsgivende i forbindelse med politiets anvendelse af peberspray.

Det anføres bl.a. i bemærkningerne vedrørende politiets brug af stav overfor passiv modstand, at hvis »kun en eller ganske få personer yder modstand ved at forholde sig passivt, « vil det »næsten undtagelsesfrit være muligt at gennemføre tjenestehandlingen ved brug af almindelig fysisk magt, det vil sige magtanvendelse uden midler.«

Stav - og formentlig også peberspray - bør således ikke anvendes mod enkeltpersoner, der udøver passiv modstand.

Undersøgelsen af praksis viser imidlertid, at når politiet anvender peberspray under henvisning til indikationsgrunden passiv modstand, så sker dette også mod enkeltpersoner. I de gennemgåede indberetninger var det tilfældet i samtlige sager.

Det fremstår endvidere ikke tydeligt, om det i disse situationer er blevet vurderet, at »tjenestehandlingens gennemførelse var uopsættelig « og at andre »mindre indgribende magtmidler [dvs. håndkraft og talens brug] var åbenbart uegnede«, således som det kræves efter $\S 25 \mathrm{a}$, nr. 6, i magtanvendelsesbekendtgørelsen.

Undersøgelsen af praksis og de gennemgåede indberetninger tyder endvidere på, at den præcise afgrænsning og rækkevidde af de seks indikationsgrunde i § 25 a i magtanvendelsesbekendtgørelsen ikke altid fremstår helt klar og konsistent. Som eksempel herpå viser gennemgangen af sagerne, at peberspray ofte anvendes, når de implicerede har en truende adfærd ( $30 \%$ af indberetningerne), herunder ved verbale trusler, jf. afsnit 4.2 ovenfor. Herudover anvendes peberspray overfor personer, der ikke vil gå væk, men som ikke er voldelige. Sådanne sager registreres som situationer vedrørende afværgelse af angreb eller overhængende fare (indikationsgrund nr. 1 og 2). Det er imidlertid ikke umiddelbart givet, at disse to indikationsgrunde efter deres ordlyd kan omfatte sager, hvor der »alene« er tale om verbale trusler eller om, at personer fx ikke følger politiets anvisninger.

Meget taler for at et så vigtigt magtmiddel som peberspray, som politiet årligt bruger langt oftere end samtlige øvrige magtmidler - skydevåben, stav, hund og gas - bør lovreguleres. Dette synspunkt støttes også af Politikommissionen, der 
har anført, at centrale områder som politiets magtanvendelsesmidler ud fra en legalitetsbetragtning bør reguleres direkte af lovgivningsmagten og fastsættes i lov, jf. afsnit 4.2. ovenfor.

\subsection{Brug af peberspray i lukkede rum}

Den Europæiske Menneskerettighedsdomstol har som nævnt fastslået, at det er uberettiget at bruge peberspray i lukkede rum, hvis andre mildere magtmidler kan anvendes, fx beskyttelsesdragt, hjelm, skjold og greb. CPT har skærpet dette og anført, at peberspray ikke bør anvendes i lukkede rum.

Undersøgelsen af praksis viser, at politiet i 30 procent af de gennemgåede sager anvendte peberspray indendørs. I 23 sager i et lukket/afgrænset rum, herunder køkkener, badeværelser, værelse på et hospital, detention mv. I syv tilfælde blev peberspray brugt $\mathrm{i}$ en patruljebil. I tre tilfælde i en personbil. Instituttet anbefaler derfor, at det bør præciseres i loven, at peberspray som udgangspunkt ikke må anvendes i lukkede rum, hvis andre mildere magtmidler kan anvendes.

\subsection{Brug af peberspray overfor psykisk syge}

Som tidligere nævnt følger det af EMRK og FN's Handicapkonvention, at politiet og andre offentlige myndigheder skal tage særligt hensyn til personer med handicap, herunder psykisk syge. CPT kritiserede i september 2014, at dansk politi havde anvendt peberspray mod en psykisk syg patient på Skt. Hans Hospital, og anbefalede, at politiet kun bruger peberspray på hospitaler i livstruende situationer.

Undersøgelsen viser, at anvendelsen af peberspray mod psykisk syge udgør et anseeligt antal i politiets statistikker. Ifølge politiets opgørelser udgjorde antallet af gange, peberspray anvendtes mod psykisk syge i 2012, 15 procent. Sagsgennemgangen viste, at peberspray både bruges i forbindelse med bæltefikseringer, hindring af selvskadende adfærd såvel ved truende og voldelig adfærd. Instituttet mener derfor, at dette bør give anledning til, at der iværksættes yderligere tiltag for at nedbringe magtanvendelse. Det bør præciseres i loven og indskærpes i praksis, at politiet kun må anvende peberspray på hospitaler i livstruende situationer og generelt indskærpes, at politiet som udgangspunkt ikke vil anvende peberspray (eller anden magt) overfor psykisk syge.

\subsection{Brug af peberspray mod personer under kontrol}

De menneskeretlige organer har fastslået, at politiet ikke må bruge peberspray mod en person, som er under kontrol. Tilsvarende anfører Politiklagemyndigheden, at politiet ikke må anvende peberspray mod en person, som politiet har opnået kontrol over. 
Vores undersøgelse af praksis viser, at der i seks af de gennemgåede sager er anvendt peberspray mod en person ilagt håndjern anbragt $i$ en patruljebil. Herudover er der tre tilfælde med personer, der er blevet lagt på jorden af politiet og derefter eksponeret med peberspray. De interviewede betjente mener ikke, at peberspray bør anvendes mod personer under kontrol. Samtidig udtrykker flere, at det er berettiget at anvende peberspray mod en person i håndjern, hvis denne ikke er under kontrol, for eksempel hvis vedkommende spytter på betjentene. Instituttet mener derfor, at det bør præciseres i reguleringen og indskærpes i praksis, at peberspray ikke må anvendes mod personer, som politiet har opnået kontrol over, herunder hvornår politiet har er opnået »kontrol« over en person.

\subsection{Brug af peberspray ved verbale trusler eller når en person ikke følger politiets anvisninger.}

EMD har anført, at der skal være klare, detajlerede og bindende retningslinjer for politiets anvendelse af peberspray.

Reglerne for benyttelse af peberspray er imidlertid ikke helt klare. Gennemgangen af sagerne viser, at peberspray anvendes hvor den eller de implicerede udelukkende er verbalt aggressiv eller ikke vil følge politiets anvisninger, uden samtidig at være voldelige. Disse sager registreres af politiet som »afværgelse af angreb eller overhængende fare. « Det er imidlertid ikke givet, at dette var intentionen med loven, og at kategorien »afværgelse af angreb eller overhængende fare« kan omfatte sager, hvor der »alene« er tale om verbale trusler eller om, at personer for eksempel ikke følger politiets anvisninger. Instituttet anbefaler derfor, at det skal gøres mere præcist $\mathrm{i}$ loven om politiet bør anvende peberspray i sådanne situationer eller om de ikke må.

\section{Politiets og Justitsministeriets reaktion - peberspray bliver reguleret i politiloven}

Instituttet har løbende været i dialog med politiet om gennemførelsen af undersøgelsen. Politiet har hjulpet med at tilrettelægge undersøgelsen, herunder foreslået politikredse, hvor interviewene med betjente kunne finde sted. Herudover har Instituttet fået aktindsigt i samtlige sager, hvor peberspray er blevet benyttet i en bestemt politikreds. Politiet har ydermere deltaget i undersøgelsens følgegruppe og er givet mulighed for at kommentere instituttets rapport, inden den blev udgivet. Et sådant samarbejde er helt nødvendigt for at kunne gennem en sådan undersøgelse. Men instituttet er samtidig opmærksom på, at det altid vil være en balance i forhold til formulering af en efterfølgende mulig kritik. 
Ud over muligheden for at kommentere rapporten, fik politiet også mulighed for at kommentere rapportens anbefalinger, inden rapporten blev udgivet. Instituttets ledelse afholdt i denne forbindelse møde med ledelsen af politiet med henblik på at diskutere resultaterne af rapporten og høre Rigspolitiets bud på, hvilke tiltag, der evt. kunne iværksættes på baggrund af rapporten. Rigspolitiet tilkendegav i juli 2015 overfor Instituttet:

»Der kan efter Rigspolitiets vurdering være gode grunde til at foretage en nærmere undersøgelse af, om der er sket væsentlige ændringer i de forudsætninger, som lå til grund for vurderingen af magtmidlets tyngde og for fastsættelse af betingelserne for magtmidlets anvendelse."

Ligeledes tilkendegav Rigspolitiet, at de vil:

»Igangsætte et arbejde med henblik på at undersøge mulighederne for at uddybe og præcisere reglerne for magtanvendelse, herunder anvendelse af peberspray.«

Rigspolitiet vil endvidere overveje, hvordan politiet kan:

»Styrke den nuværende videreformidling af konkrete afgørelser om brug af magtmidler, herunder navnlig afgørelser, hvor der er fundet grundlag for at kritisere politiets magtanvendelse, til ledere og medarbejdere. ${ }^{49}$

Det er positivt, at politiet således vil have et særligt fokus på brugen af peberspray.

Justitsministeren fremsatte d. 5. oktober 2016 lovforslag om ændring af politiloven, således at politiets anvendelse af peberspray nu reguleres i politiloven. ${ }^{50}$

Det er positivt, at indikationsgrundene for at anvende peberspray nu lovfæstes. Bemærkninger til lovforslaget adresserer endvidere en række af anbefalingerne fra vores undersøgelse. Det understreges således, at politiet altid skal foretage en konkret nødvendigheds- og proportionalitetsvurdering inden brug af peberspray. Ligesom bemærkningerne indeholder en udførlig - næsten fire sider - forklaring og præcisering af indikationsgrundene for brug af peberspray. Det præciserer herved bl.a., at »hvis en eller ganske få personer yder modstand ved at forholde sig passivt, må det antages, at det næsten undtagelsesfrit vil være muligt at gennemføre tjenestehandlingen ved brug af almindelig fysisk magt.« (dvs. uden peberspray eller andre magtmidler). Videre anføres det i bemærkningerne, som vi også anbefalede, at 
»Der vil dog være situationer, hvor der generelt bør udvises særlig tilbageholdenhed med anvendelse af peberspray, f.eks. i tilfælde hvor et køretøj ønskes bragt til standsning eller i tilfælde, hvor en person er ilagt håndjern. «" (kursiv tilføjet).

Der er dog også visse af instituttets anbefalinger, som ikke direkte adresseres i lovforslaget eller i bemærkningerne hertil. Det drejer sig om brug af peberspray på hospitaler og mod psykisk syge og om politiets brug af peberspray i lukkede rum. Det kan i den forbindelse fremhæves, at Direktoratet for Kriminalforsorgen efter Institut for Menneskerettigheders undersøgelse af brugen af peberspray i fængsler og arresthuse i 2015, og i overensstemmelse med prakis fra EMD, har indskærpet over for samtlige fængsler og arresthuse, at »personalet skal være varsomme med at anvende peberspray i lukkede rum (indsattes celle). $\ll^{52}$

Det nye forslag til politilov er endnu ikke vedtaget, men må formodes at blive det i løbet af efteråret 2016. Det er således vores opfattelse, at vores undersøgelse og samarbejde med politiet har ført til - eller i det mindste medvirket til - at politiet nu har øget fokus på at begrænse brugen af peberspray, ligesom adgang til at anvende peberspray vil blive præciseret, skærpet og lovfæstet.

\section{Noter}

1. Lisbeth Garly Andersen er antropolog og ansat som specialkonsulent på Institut for Menneskerettigheder.

2. Peter Vedel Kessing er Cand. Jur., Ph.D. og ansat som seniorforsker på Institut for Menneskerettigheder og ekstern lektor på Juridisk Fakultet, Københavns Universitet.

3. J.f. bekendtgørelse nr. 1430 af 11. december 2007 om ændring af bekendtgørelse om politiets anvendelse af visse magtmidler mv.

4. Beskrivelsen stammer fra det lovforslag, hvor peberspray blev indført som magtmiddel i Kriminalforsorgen, jf. lovforsalg nr. L. 93, Lov om ændring af lov om fuldbyrdelse af straf m.v., fremsat d. 8. december 2010, pkt. 2.1.2., side 3 .

5. 2006-07 - Svar på § 20-spørgsmål: Om peberspray. Spørgsmål nr. S 2384. Justitsministerens (Lene Espersen) svar til Hans Kristian Skibby. Sundhedsstyrelsens notater af 3. marts 2009 og 28. april 2010 om $\gg$ Sundhedsstyrelsens udtalelse om eventuelle medicinske skadesvirkninger ved anvendelse af OC-spray/peberspray«.

6. Lars Holmberg. Politiets brug af peberspray - en skandinavisk sammenligning med fokus på Danmark. Nordisk Tidsskrift for Kriminalvidenskab 100 (1) 89-111.

7. Selve undersøgelsen kan findes her http://menneskeret.dk/udgivelser/brug-peberspraydansk-politi

8. Instituttet har valgt at anonymisere, hvilken kreds der er blevet udvalgt i forhold til gennemgangen af indberetninger.

9. Se $»$ Brug af Peperspray i danske fængsler og arresthuse«. Institut for Menneskerettigheder 2014. Se også Lisbeth Garly Andersen og Peter Vedel Kessing, Brug af peberspray i dan- 
ske feengsler og arresthuse, Nordisk Tidsskrift for Kriminalvidenskab, maj 2016, 103. årgang nr. 1, s. 61-62.

10. Tallene fremgår af Rigspolitiets opgørelse over magtanvendelse i 2014. https://www.politi.dk/ NR/rdonlyres/21B42634-BBE5-4FC9-B050-A0244127239B/0/Politietsbrugafmagtmidler 2014.pdf.

11. https://www.politi.dk/NR/rdonlyres/21B42634-BBE5-4FC9-B050-A0244127239B/0/Politi etsbrugafmagtmidler2014.pdf.

12. Se endvidere Institut for Menneskerettigheders rapport 'Brug af peberspray i dansk politi' 2015.

13. Politiet kan angive flere årsager til en hændelse. Totalen bliver derfor ikke 100 procent.

14. Rigspolitiet har ikke detaljerede tal for 2013 og 2014, kun tal over den samlede anvendelse af peberspray. Derfor er 2013 og 2014 tallene ikke med i tabellen.

15. Skema af 25. april 2013 kommer fra www.politi.dk. Kan findes her: https://www.politi.dk/ da/aktuelt $/$ nyheder/K15 nyheder_250413.htm

16. Politiets brug af skydevåben falder uden for rammerne af dette notat.

17. Jf. bl.a. Ib Henricson, Politiret, 5. udgave, DJØF, s. 237.

18. Jf. Politikommissionen, Betcenkning om Politilovgivning, Betænkning 1410, 13. december 2001, s. 103.

19. Jf. note 1 .

20. Magtbekendtgørelsen fra 2004 blev ændret i 2007, hvorved bestemmelserne $\S 25$ a, b og c om politiets brug af peberspray blev indsat $\mathrm{i}$ bekendtgørelsen.

21. Magtbekendtgørelsen fra 2004 blev ændret i 2007, hvorved bestemmelserne $\S 25$ a, b og c om politiets brug af peberspray blev indsat $\mathrm{i}$ bekendtgørelsen.

22. Jf. Politi.dk, Politiets brug af magtmidler. 25. april 2013. Kan findes her: https://www.politi.dk/ da/aktuelt/nyheder/K15_nyheder_250413.htm (sidst besøgt januar 2014).

23. Jf. bemærkninger til lovforslag om politiets virksomhed, 2003/1 1sf. 159, fremsat den 4. februar 2004, de særlige bemærkninger til § 15.

24. Se note ovenfor.

25. Ordlyden af de to bestemmelser - og de situationen hvor der kan anvendes stav og hund er helt identisk bort set fra, at der i $\$ 19$ om anvendelsen af hunde er indsat én yderligere situation, hvor der kan anvendes hund - nemlig »nr. 5. at sikre pågribelsen af personer.«

26. Jf. bemærkninger til lovforslag om politiets virksomhed, 2003/1 1sf. 159, fremsat den 4. februar 2004, de særlige bemærkninger til $§ 15$, gengivet nedenfor i afsnit med lille skrift under pkt. 6) »Passiv modstand«.

27. Jf. note 10 ovenfor.

28. Jf. note 10 ovenfor.

29. Det gælder dog kun, når stav tages i brug med henblik på rydning af gader, bygninger m.v. for et større antal personer, jf. § 18, stk. 2, i politiloven.

30. Jf. Rigspolitiet, Evaluering af forsøg med peberspray, s. 7, 16. januar 2007.

31. Jf. note 24, s. 13.

32. Jf. note 24, s. 12.

33. Herunder Institut for Menneskerettigheder. Instituttets høringssvar af 29. oktober 2007 kan findes her: http://menneskeret.dk/viden/h\%c3\%b8ringssvar/2007/2007?doc $=18800$

34. Rigspolitichefen, Kundgørelse II nr. 57 Om politiets brug af peberspray. 
35. Betingelserne for at anvende tåregas er som nævnt $i$ afsnit 4.4.1. en anelse lempeligere.

36. Den Uafhængige Politiklagemyndighed, Årsberetning 2013, s. 13.

37. Jf. note 80 , s. 13-14.

38. Antallet kan være vanskeligt at afgøre præcist. En sag er taget med, hvis det direkte er angivet $\mathrm{i}$ indberetningerne, at en person for eksempel har sparket eller slået. Hvis det blot hedder i sagen, at personen satte sig til modværge, indgår denne sag ikke.

39. Betjentene er ikke blevet spurgt om, hvordan de har kategoriseret de enkelte tilfælde. En gennemgang af indberetningerne viser imidlertid, at hændelserne sandsynligvis vil være placeret under kategorierne »afværgelse af påbegyndende eller overhængende angreb på person«, »afværgelse af fare for personers liv eller helbred« eller gennemførelse af tjenestehandlinger mod hvilke, der gøres aktiv modstand."

40. Anholdelsessituationer er både placeret i kategorierne »gennemførelse af tjenestehandlinger mod hvilke, der gøres aktiv modstand«, »afværgelse af påbegyndende eller overhængende angreb på person« og »afværgelse af fare for personers liv eller helbred«.

41. Politiet har placereret disse sager under henholdsvis »gennemførelse af tjenestehandlinger mod hvilke, der gøres aktiv modstand«, »afværgelse af påbegyndende eller overhængende angreb på person« og »afværgelse af fare for personers liv eller helbred«.

42. Politiet kan afkrydse i flere felter. En person kan således registreres som både spiritus og narkotikapåvirket på en gang.

43. Oplysninger i brev af 6. juli 2015 fra Rigspolitiet til Institut for Menneskerettigheder.

44. Sagsnummer 22/12, 91/12, 123/12. Se sagerne gengivet i rapporten »Brug af peberspray $i$ dansk politi.« Institut for Menneskerettigheder 2015.

45. Sagsnummer 5/12, 17/12, 115/12, 131/12, 89/12, 34/12. Se sagerne gengivet i rapporten »Brug af peberspray i dansk politi.« Institut for Menneskerettigheder 2015.

46. Sagsnummer 39/12,60/12, 130/12. Se sagerne gengivet i rapporten »Brug af peberspray i dansk politi.« Institut for Menneskerettigheder 2015.

47. For eksempel sagerne 142/12 og 148/12. Se sagerne gengivet i rapporten »Brug af peberspray i dansk politi.« Institut for Menneskerettigheder 2015.

48. For en nærmere beskrivelse af de nævnte myndigheders vurdering af pebersprays farlighed se Lisbeth Garly Andersen og Peter Vedel Kessing, Brug af peberspray i danske fangsler og arresthuse, Nordisk Tidsskrift for Kriminalvidenskab, maj 2016, 103. årgang nr. 1, s. 61-62.

49. Brev fra Rigspolitiet til Institut for Menneskerettigheder 6. juli 2015.

50. Jf. lovforslag nr. L 17. Lov om aendring af lov om forbud mod besøgende i bestemte lokaler og lov om politiets virksomhed (Initiativer mod handel med hash m.v. og politiets anvendelse af peberspray).

51. Ibid.

52. Jf. note 9 . 